\title{
Review \\ Bleeding and Thrombosis: Insights into Pathophysiology of Bothrops Venom-Related Hemostasis Disorders
}

\author{
Sébastien Larréché ${ }^{1,2}$, Jean-Philippe Chippaux ${ }^{3,4}$, Lucie Chevillard ${ }^{1}\left(0\right.$, Simon Mathé ${ }^{1}$, Dabor Résière ${ }^{5}\left({ }^{\circ}\right.$, \\ Virginie Siguret ${ }^{6,7}$ and Bruno Mégarbane ${ }^{1,8, *(1)}$ \\ 1 INSERM, UMRS-1144, Paris University, 75006 Paris, France; slarreche@hotmail.fr (S.L.); \\ luciechevillard@gmail.com (L.C.); sim.mathe@gmail.com (S.M.) \\ 2 Department of Medical Biology, Bégin Military Teaching Hospital, 94160 Saint-Mandé, France \\ 3 MERIT, IRD, Paris University, 75006 Paris, France; jean-philippe.chippaux@ird.fr \\ 4 CRT, Pasteur Institute, 75015 Paris, France \\ 5 Clinical Toxicology Unit, Critical Care Department, University Hospital of Martinique, Fort de France, \\ 97200 Martinique, France; Dabor.RESIERE@chu-martinique.fr \\ 6 INSERM, UMRS-1140, Paris University, 75006 Paris, France; virginie.siguret@aphp.fr \\ 7 Laboratory of Hematology, Lariboisière Hospital, 75010 Paris, France \\ 8 Department of Medical and Toxicological Critical Care, Lariboisière Hospital, 75010 Paris, France \\ * Correspondence: runo.megarbane@lrb.aphp.fr; Tel.: +33-(0)-143-985-299
}

Citation: Larréché, S.; Chippaux, J.-P.; Chevillard, L.; Mathé, S.; Résière, D.; Siguret, V.; Mégarbane, B.

Bleeding and Thrombosis: Insights into Pathophysiology of Bothrops Venom-Related Hemostasis Disorders. Int. J. Mol. Sci. 2021, 22, 9643

https://doi.org/10.3390/ijms22179643

Academic Editor: Loïc Quinton

Received: 2 August 2021

Accepted: 3 September 2021

Published: 6 September 2021

Publisher's Note: MDPI stays neutral with regard to jurisdictional claims in published maps and institutional affiliations.

Copyright: (c) 2021 by the authors. Licensee MDPI, Basel, Switzerland. This article is an open access article distributed under the terms and conditions of the Creative Commons Attribution (CC BY) license (https:// creativecommons.org/licenses/by/ $4.0 /)$.

\begin{abstract}
Toxins from Bothrops venoms targeting hemostasis are responsible for a broad range of clinical and biological syndromes including local and systemic bleeding, incoagulability, thrombotic microangiopathy and macrothrombosis. Beyond hemostais disorders, toxins are also involved in the pathogenesis of edema and in most complications such as hypovolemia, cardiovascular collapse, acute kidney injury, myonecrosis, compartmental syndrome and superinfection. These toxins can be classified as enzymatic proteins (snake venom metalloproteinases, snake venom serine proteases, phospholipases $\mathrm{A}_{2}$ and L-amino acid oxidases) and non-enzymatic proteins (desintegrins and C-type lectin proteins). Bleeding is due to a multifocal toxicity targeting vessels, platelets and coagulation factors. Vessel damage due to the degradation of basement membrane and the subsequent disruption of endothelial cell integrity under hydrostatic pressure and tangential shear stress is primarily responsible for bleeding. Hemorrhage is promoted by thrombocytopenia, platelet hypoaggregation, consumption coagulopathy and fibrin(ogen)olysis. Onset of thrombotic microangiopathy is probably due to the switch of endothelium to a prothrombotic phenotype with overexpression of tissue factor and other pro-aggregating biomarkers in association with activation of platelets and coagulation. Thrombosis involving large-caliber vessels in B. lanceolatus envenomation remains a unique entity, which exact pathophysiology remains poorly understood.
\end{abstract}

Keywords: snake venom; hemorrhage; microthrombi; thrombocytopenia; coagulopathy

\section{Introduction}

Bothrops snakes, also called lanceheads, are the main genus of medical importance in the Neotropical Americas. They are involved in most cases of envenomation in studies performed in Brazil [1-5], Ecuador [6], French Guiana [7], Colombia [8], Argentina [9], Costa Rica [10] and Panama [11]. Belonging to the Viperidae family and the Crotalinae subfamily, Bothrops genus comprises nearly 50 species, widely distributed in South and Central America (from southern Mexico to Argentina) and in the Caribbean. Lanceheads usually occupy terrestrial, arboreal and semiarboreal biotopes, but may be occasionally found in disturbed habitats around human settlements and urban areas [12,13]. The main species involved in human envenomations are B. atrox in the Amazon region, B. asper from southern Mexico to western Ecuador and Colombia, and B. jararaca in South East Brazil, Argentina and Paraguay, with a large body of medical literature for these three 
taxons [11,13-16]. B. atrox and B. asper are phylogenetically close and belong to the $B$. atrox group $[12,17]$. Fenwick et al. has proposed to assign $B$. jararaca to a new genus, Bothropoides [18], subsequently considered synonym of Bothrops [19].

Snake venoms contain a highly potent mixture of bioactive molecules, known as toxins. Toxins from Bothrops venom exhibit a great diversity and are predominately represented by snake venom metalloproteinases (SVMP), snake venom serine proteinases (SVSP), phospholipases $\mathrm{A}_{2}\left(\mathrm{PLA}_{2}\right)$, C-type lectin-like toxins (CTL), desintegrins, cysteine-rich secretory proteins (CRISP), L-amino acid oxidases (LAAO), natriuretic peptides including vasoactive peptides, bradykinin potentiating and inhibitory peptides [20]. Bothrops venoms have various targets against hemostasis. This process aims to stop or limit bleeding after vascular injury. The three distinct phases, primary hemostasis (mainly involving platelets), coagulation (related to fibrin formation) and fibrinolysis, are closely linked [21]. The von Willebrand factor (vWF) is a multimeric protein present in the subendothelium and in plasma where it is conformationally activated by shear forces. Injured vessel wall recruits platelets via vWF; platelets are activated, recruit additional platelets and form a platelet aggregate [22]. Initiation of the coagulation pathway is secondary to exposure to tissue factor (TF) and formation of TF/factor VII activated (VIIa) complex, which activates small amounts of FIX and FX. Then, two overlapping stages occur with amplification in which platelets and cofactors are activated to set the stage for large scale thrombin generation, and propagation in which large amounts of thrombin are generated on the platelet surface [23]. During fibrin formation, the $\mathrm{N}$-terminal part of the $\mathrm{A} \alpha$ and $\mathrm{B} \beta$ chains (within the $\mathrm{E}$ region) are cleaved by thrombin, releasing fibrinopeptides $\mathrm{A}$ and $\mathrm{B}$. This cleavage results in the unmasking of four binding sites on the E region, each site being able to bind to the $\mathrm{C}$ terminal portion of a $\mathrm{D}$ region from fibrin monomers. In this way, monomeric fibrin self-assemblies spontaneously yield fibrin oligomers that lengthen to make two-stranded protofibrils [24]. Thrombin also activates factor XIII that cross-links fibrin polymers leading to the formation of an insoluble fibrin net. Several control mechanisms exist for localizing fibrin formation to the site of injury including tissue factor pathway inhibitor, protein C system, antithrombin, and glycosaminoglycans on the endothelium [25]. Fibrinolysis is a highly regulated process, starting with fibrin formation and activation of the tissue plasminogen activator (tPA) on plasminogen-binding sites. Release of tPA from endothelial cells leads to the conversion of proenzyme plasminogen into plasmin [26]. Plasmin digests the fibrin component of the blood clot. Inhibition of the fibrinolytic system occurs at the level of the plasminogen activator (by plasminogen activator inhibitor type 1, PAI-1) or at the level of plasmin (by $\alpha_{2}$-antiplasmin, $\alpha_{2}$-AP) [22].

Local features of Bothrops envenomation are pain, edema, bruising, bleeding from fang punctures, sometimes blistering or dermonecrosis [13,16,27]. Hemorrhagic syndrome remains the most important cause of lethality associated with these species [5,28,29], while other complications may occur: acute kidney injury (AKI), shock, myonecrosis, compartment syndrome and secondary infections $[16,30]$.

B. lanceolatus and B. caribbaeus, found only in Martinique and Saint Lucia, respectively, also belong to the B. atrox group [12,17]. Despite an initial local presentation similar to that described during envenomation by B. atrox or B. asper including local hemorrhage and ecchymosis, envenomations due to these Caribbean species are unusually associated with systemic bleeding and incoagulabiblity, but may by contrast be complicated by multiple systemic infarctions within $48 \mathrm{~h}$ after the bite [31].

Thus, hemostasis disorders induced by Bothrops venoms are responsible, directly or indirectly, for a large number of clinical impairments, sources of marked morbidities and potential fatality. Understanding the underlying mechanisms is therefore challenging as prerequisite to optimize current management strategies and develop new approaches. 


\section{Clinical Manifestations Induced by Hemostasis Disorders during Bothrops Envenomations}

\subsection{Bleeding}

\subsubsection{Local Hemorrhage}

A discrete trickle of blood from the fang punctures starts minutes after the bite with venom injection, even in the absence of systemic signs and blood incoagulability $[28,29,32,33]$. A local ecchymosis around the bite site is another classical feature and seems more frequent in children [28,33]. Blisters around or far from the bite in the affected limb may appear within the first $24 \mathrm{~h}$ and contain a serohematic or a bloody content, to be considered as manifestation of local hemorrhagic syndrome [13].

\subsubsection{Systemic Hemorrhage}

Mucosal hemorrhages are the earliest manifestations of systemic bleeding. Gingival bleeding and hematuria are the most frequent but other mucous membranes may occur with epistaxis, conjunctival bleeding, otorrhagia and metrorrhagia [28,29,32,33]. Hemorrhagic skin and subcutaneous manifestations are also reported including petechiae, ecchymosis or hematoma, bleeding through recent wounds or veni-puncture site $[16,28,29,34]$.

Visceral hemorrhages are less frequent but more severe and may include hemarthrosis (finger joints, knee) [16], hepatic or retroperitoneal hematoma [16,35], hemothorax [32,36], pulmonary hemorrhage [37], hematemesis and rectal bleeding [28,29]. Central nervous system hemorrhages are a dreadful complication and may be intracerebral, intraventricular, subarachnoid, subdural, extradural, cerebellar or medullar $[16,38,39]$. In a study on the prevalence of cerebrovascular complications in Bothrops envenoming, it was found that $2.6 \%$ of the victims developed a cerebrovascular event, of which about $60 \%$ died and $40 \%$ remained with sequelae [40]. Delay in antivenom administration may contribute to the onset of such complications $[16,38,41]$. Systemic bleeding is significantly associated with higher snakebite fatality [5] and amputation [42].

\subsubsection{Thrombocytopenia and Incoagulability}

Thrombocytopenia and unclottable blood on admission are independently associated with systemic bleeding during hospitalization for $B$. atrox et $B$. jararaca envenomation $[29,43,44]$.

Clinical studies in patients bitten by $B$. jararaca evidenced that systemic bleeding is more frequent in patients with thrombocytopenia than in patients with blood incoagulability $[45,46]$. By contrast, thrombocytopenia is an infrequent event in envenomations in the Amazon, mainly caused by B. atrox [28,43]. A negative correlation was found between the number of platelets and the mean platelet volume on patient admission for an envenomation by $B$. atrox, suggesting peripheral platelet destruction, which tends to increase the mean platelet volume [29]. Thrombocytopenia on admission is also a useful prognostic indicator of local complication development such as necrosis [44].

The hemorrhagic syndrome is exacerbated by incoagulability $[28,29]$. Unclottable blood due to consumption coagulopathy and defibrinogenation usually occurs within one hour [16]. In contrast, patients with only local bleeding and without bleeding may often show normal levels of hemostatic factors and fibrinolysis parameters [43].

Envenomed patients present increased prothrombin time (PT) and activated partial thromboplastin time (aPTT), with low level of fibrinogen. Factors II, V, VII, X, XIII also decrease $[43,47,48]$. Factors involved in the intrinsic pathway (factors VIII, IX, XI, XII) are less frequently reduced $[47,48]$.

PT and aPTT take respectively 3 and 1 day(s) to normalize without antivenom. Fibrinogen level reaches $100 \mathrm{mg} / \mathrm{dL}$ in $24 \mathrm{~h}$ [49]. In mice, injection of B. jararaca venom upregulates hepatic mRNA synthesis of fibrinogen chains, which may explain the fast recovery of clotting tests and fibrinogen level, even without antivenom [50].

Owing to its low cost, simplicity and good correlation with plasma fibrinogen concentration, the $20 \mathrm{~min}$ whole blood clotting test (20WBCT) is an effective and reliable method for evaluation of hemostatic status in the primary care centers without laboratory [51]. In- 
creased levels of plasma TF are detected and may contribute to the intravascular generation of thrombin as suggested by high levels of thrombin-antithrombin complexes, leading to a transient hypercoagulable state, then to incoagulability and systemic bleeding $[43,45,52]$.

Secondary hyperfibrinolysis was observed in patients envenomed by B. atrox in Manaus, especially those with systemic bleedings, high levels of D-dimers and fibrin/fibrinogen degradation products (FDP) and low levels of plasminogen and $\alpha_{2}$-AP $[28,43]$. This fibrinolysis seems to be in response to fibrin deposition, in order to avoid microvascular thrombotic obstruction.

High levels of PAI-1 and tPA as well as increase in vWF and thrombomodulin were recorded in patients bitten by $B$. jararaca evolving with systemic bleeding with or without incoagulable blood, suggesting that the fibrinolysis is also due to vascular endothelial damage $[45,52]$.

\subsection{Thrombosis}

\subsubsection{Thrombotic Microangiopathy}

Thrombotic microangiopathy (TMA) was recently described in envenomation cases by B. jararaca [53,54], B. venezuelensis [55] and B. erythromelas [56]. These patients presented on admission a classic local syndrome with pain, edema, local ecchymosis or bleeding at the fang punctures, but no systemic bleeding. Coagulopathy resolved within 12-24 $\mathrm{h}$ after antivenom infusion, whereas the features associated with TMA (thrombocytopenia, hemolytic anemia with presence of schistocytes in blood smears, decreased haptoglobin level, increased lacticodehydrogenase (LDH) level and AKI) tended to start 1-3 days post-bite despite antivenom and persisted for longer. In the case of $B$. venezuelensis bite, hyperfibrinogenemia began at day 2 and persisted over 2 weeks despite the administration of antivenom $4.5 \mathrm{~h}$ after the bite [55]. When assayed, ADAMTS13 activity and C3/C4 complement levels were within the normal range [54].

In a fatal case due to massive pulmonary hemorrhage occurring $1 \mathrm{~h}$ after $B$. jararacussu bite, autopsy reported evidence of multiple fibrin and platelet microthrombi in the subcutaneous and muscular tissue around the bite site, and in the heart and lung microcirculations [37]. Bleeding and microthrombosis may occur simultaneously and therefore be considered as part of the same nosological framework.

\subsubsection{Macrothrombosis}

B. lanceolatus is responsible for 20-30 snakebite cases in Martinique each year [57]. Approximatively $30 \%$ to $40 \%$ of the B. lanceolatus envenomations are associated with systemic multifocal thrombotic complications, usually occurring within $5 \mathrm{~h}$ to a week after the bite, even after a moderate envenomation limited to local signs $[31,58,59]$. Thromboses involve cerebral, myocardial, pulmonary and femoral arteries, and may lead to death or major functional sequelae in the absence of specific antivenom [58]. More than half of the patients envenomed by $B$. lanceolatus have thrombocytopenia while rare patients develop disseminated intravascular coagulation. Thrombocytopenia, minimally reduced prothrombin, normal activated partial thromboplastin time, and elevated fibrinogen concentration are typical features in B. lanceolatus-envenomed patients who will further develop thromboses $[57,59]$.

A fatal case of $B$. lanceolatus envenomation with diffuse thrombotic microangiopathy causing multiple cerebral, myocardial and mesenteric infarctions at autopsy was reported. Laboratory features associated hemolytic anemia with increased LDH and biblirubin levels, thrombocytopenia and hyperfibrinogenemia with minimally reduced prothrombin ratio and normal activated partial thromboplastin time [60].

A similar clinical presentation was reported in a patient bitten by B. caribbaeus in Saint-Lucia, who developed multiple cerebral infarctions [61]. 


\subsection{Complications Associated to Hemostasis Disorders}

Beyond the hemorrhagic consequences, microcirculation impairment around the bite site may partly explain the edematogenic process due to vascular permeability increase $[62,63]$. Additionally, systemic bleeding and hemostatic disturbances contribute to hypovolemia, hypotension, tissue hypoperfusion, cardiovascular shock and cerebrovascular events $[5,64,65]$.

Presence of thrombi in arterioles and arteries associated to local microcirculation impairment may contribute to limit vascularization of distal muscle tissues leading to poor regeneration of muscles and local myonecrosis followed by secondary infection [27]. AKI is the leading cause of lethality among patients surviving the early effects of Bothrops venom [66]. Glomerular microthrombi due to venom-induced thrombin generation, endothelial injury and intravascular hemolysis represent the main pathways for Bothrops envenomation-related AKI development $[67,68]$. Finally toxins involved in thrombi may lead to systemic inflammation and amplify this process [69].

\subsection{Response to Antivenom}

Antivenom is the first-line treatment of snakebite envenomation and its related hemostasis disorders. It consists of polyclonal antibodies generated by immunizing animals with small amounts of snake venom. The resulting antibodies are purified from serum or plasma and formulated into intact IgG or $\mathrm{F}\left(\mathrm{ab}^{\prime}\right)_{2}$ or Fab-fragment therapies to be administered intravenously [70].

The majority of patients showed rapid restoration of blood coagulability and cessation of bleeding [32,34,71-73]. Bleedings (except hematuria) are corrected in most patients 6-12 h after antivenom following B. atrox $[28,74]$ and B. asper [32,71] bites. Hematuria correction is slower, about 12-24 h after antivenom administration [16]. In some cases, patients without systemic bleeding on admission started to bleed after antivenom but these manifestations did not persist [28]. Blood coagulation is restored most of the time within $6-24 \mathrm{~h}$ after antivenom $[28,32,48,71,72]$. Clotting tests and fibrinolysis parameters return to normal around $48 \mathrm{~h}$ after antivenom [28,47,49].

In French Guiana, a non-local antivenom (Antivipmyn $\operatorname{Tr}^{\circledR}{ }^{\circledR}$, Instituto Bioclon, Ciudad de México, Mexico) is currently used to treat snakebites including B. atrox envenomations. A retrospective study shown that compared to patients receiving no antivenom, the 3-vials dosage initially used had no benefit in correction of snakebite-related coagulopathy [49]. In a second study with an increased dosage to 6 vials for most patients, a reduction in the time to return to normal clotting tests was observed for patients who received this antivenom in comparison to those who did not, but with a higher rate of early adverse reactions [47]. It therefore appears necessary to optimize treatment and evaluate other antivenoms in this French overseas department.

Bothrops bite-related TMA occur despite specific antivenom but still have a good prognosis $[53,55,56,60]$.

A monovalent antivenom against B. lanceolatus venom, Bothrofav ${ }^{\circledR}$ (Micropharm Limited, Newcastle Emlyn, UK), prevents thrombosis if it is early given, up to $6 \mathrm{~h}$ following the bite [75]. Since its introduction in 1993, the mortality rate decreased [57]. However some patients developed cerebral infarctions within $24 \mathrm{~h}$ despite early administration of Bothrofav $^{\circledR}$ [76]. In these cases, as reported in cases of snakebite-related TMA, coagulopathy was quickly resolved whereas thromboses occurred with a delay [76]. Anticoagulant and thrombolytic treatment is of limited efficacy to prevent these thrombotic complications [31,58].

\section{Toxins Involved in Bothrops Venom-Related Hemostasis Disorders}

Snake venoms are complex mixtures of proteins with toxic activities, with many distinct isoforms, affecting different physiological targets, including enzymes and nonenzymatic proteins. Toxins isolated from Bothrops venoms and involved in hemostasis disorders are classified into different families. 


\subsection{Enzymatic Proteins}

\subsubsection{Snake Venom Metalloproteinases}

SVMP are zinc-dependent endopeptidases belonging to the metzincin family [77]. They represent the predominant protein family in Viperinae and Crotalinae venoms, especially in Bothrops venoms [20]. They display several activities resulting in hemorrhage, proteolytic degradation of fibrinogen and fibrin, activation of factors II (prothrombin) and $X$, apoptosis, platelet aggregation or inhibition, inflammation induction and inhibition of blood serine proteinase inhibitors [78]. Based on their size and domain structure, these multi-domain proteins have been classified in P-I, P-II and P-III classes [78].

The mature protein forms of P-I SVMP (20-30 kDa) contain a catalytic domain characterized by a zinc-binding sequence (HEXXHXXGXXH) followed by a conserved "Methionine-turn" motif. The P-I SVMP are divided into two subgroups, i.e., P-IA which induce hemorrhage and P-IB with weak (or no) hemorrhagic effects [79]. Structural comparisons of hemorrhagic and non-hemorrhagic P-I SVMP from snake venoms revealed differences in the loop comprising residues 153 to 176 adjacent to the methionine-turn, conferring a higher flexibility in the loop area of hemorrhagic P-I SVMP [80]. This difference could influence the interaction with relevant substrates in the extracellular matrix [81,82].

Class P-II includes enzymes containing the metalloproteinase domain described above and a disintegrin domain (30-60 kDa). Disintegrins have most often an RGD motif which is the primary recognition site for the integrin $\alpha_{\mathrm{IIB}} \beta_{3}$ (fibrinogen receptor, also known as GP IIb/IIIa) inhibiting platelet aggregation [83]. This canonical RGD motif is not always present in all P-II SVMP and could be replaced by a KGD, VGD, WGD, MLD, RTS or KTS motif [84].

P-III SVMP (60-100 kDa) contain a metalloproteinase catalytic domain and disintegrinlike and cysteine-rich domains in a single polypeptide chain, many of them being glycosylated. Proteolytic cleavage, repeated domain loss and presence of other ancillary domains are responsible for structural diversities of P-II and P-III SVMP. The former P-IV class characterized by the addition of a lectin-like domain is now considered as a P-III class (P-IIId) due to a post-translational modification [84]. Jararhagin is a hemorrhagic P-III SVMP, isolated from the venom of $B$. jararaca [85]. Because both recombinant jararhagin and native deglycosylated jararhagin did not show any hemorrhagic activity in a murine model, the hemorrhagic properties of SVMP seem to be dependent on post-translational modifications [86].

\subsubsection{Snake Venom Serine Proteases}

SVSP have a typical trypsin fold with a highly reactive serine residue in their active site and catalyze the cleavage of specific covalent bonds in peptides and proteins [87]. These enzymes affect various systems including hemostasis, complement, blood pressure and nervous system. Activities of SVSP interfering with hemostasis may be procoagulant or anticoagulant. Procoagulant proteases are distinguished between enzymes able to activate factors II, VII and/or X and enzymes named thrombine-like enzymes (TLE) which cleave fibrinogen in fibrin. Other activities against hemostasis are direct fibrin(ogen)olysis, activation of protein $C$ and plasminogen, inhibition of antithrombin, PAI- 1 and $\alpha_{2}$-AP. SVSP isolated from Bothrops venoms are most often TLE or fibrin(ogen)olytic $[87,88]$.

\subsubsection{Phospholipases $A_{2}$}

$\mathrm{PLA}_{2}$ are small proteins with the molecular mass of $13-15 \mathrm{kDa}$. $\mathrm{PLA}_{2}$ hydrolyze the ester linkages in glycerophospholipids at the $s n-2$ positions to produce equimolar amounts of lysophospholipids and free fatty acids. It requires calcium for their catalytic actions. Their structure has three major $\alpha$-helices and two antiparallel $\beta$-sheets cross-linked by disulfides bonds. Snake venom PLA 2 are classified into two groups, I and II, according to the location of disulfide bonds $[89,90]$. PLA $A_{2}$ from Bothrops venoms belong to group II. Asp 49 and Lys $_{49}$ are the most well studied PLA 2 of group II. These PLA 2 are classified according to the amino acid located at position 49 [91]. 
They display a wide range of biological effects such as neurotoxicity, cardiotoxicity, local or systemic myotoxicity, hemolysis, and anticoagulating, antiplatelet and edemaforming activities.

\subsubsection{L-Amino Acid Oxidases}

LAAO are homodimeric flavoenzymes that catalyze the stereospecific oxidative deamination of L-amino acid to $\alpha$-keto acid and produce hydrogen peroxide. These enzymes have a molecular mass of 110-159 kDa and three major domains: substrate-binding domain, FAD-binding domain and helical domain.

LAAO can inhibit or induce platelet aggregation, depending on the isoform. In addition, LAAO may be responsible for edema, inflammation, apoptosis, hemolysis and hemorrhage [92].

\subsection{Non-Enzymatic Proteins}

\subsubsection{Disintegrins}

Disintegrins are small polypeptides (40-100 amino-acid) derived by proteolytic processing from P-II SVMP or from genes solely encoding disintegrins (so called true or short-coding disintegrins) [83]. They are carrying the integrin recognition motifs (RGD and its variants). They are divided into several groups, depending of their molecular mass and their number of cysteine bridges [93].

Most of their toxic effects are due to their interaction with cell surface ligands: inhibition of platelet aggregation, apoptosis, cytotoxicity. Moreover, they interfere with the functions of integrins by altering different cellular processes such as migration, adhesion or proliferation [94].

\subsubsection{C-Type Lectin Proteins}

Snake venom CTL bind to mono- and oligo-saccharides in a calcium-dependent manner. They are distinguished between classical CTL possessing a carbohydrate recognition domain that binds to sugars, and non-sugar-binding C-type lectin-related proteins, also called snaclecs. Snaclecs are more widely present in snake venoms than classical CTL. While CTL are disulfide-linked homodimers or homo-oligomers, snaclecs are disulfide-bonded heterodimers or oligomeric complexes of heterodimers including two highly homologous subunits tightly associated by loop-swapping, with a concave surface between the two subunits. The concave surface is probably the main ligand binding site [95].

Most classical CTL isolated in snake venoms bind to galactose and induce platelet aggregation. Snaclecs could be agonists or antagonists of platelet aggregation, or anticoagulant (FIX-, FX- or $\alpha$-thrombin-binding) $[88,96]$.

\subsection{Venom Variability}

Venoms of B. lanceolatus and B. caribbaeus, rather associated with the occurrence of thrombosis, mainly contain SVMP, PLA 2 , SVSP, LAAO [97] and do not differ significantly in the composition from other venoms belonging to this genus responsible for systemic bleeding (Table 1). The total relative amount of SVMP was found to be approximatively the same in the venoms of B. jararaca and B. lanceolatus, the difference being in the distribution of SVMP subgroups. B. lanceolatus has relatively more P-I SVMP identified than B. jararaca venom while $B$. jararaca venom has a higher amount of hemorrhagic P-III SVMP [98]. On the other hand, Gutierrez et al. found a predominance of P-III SVMP in both B. lanceolatus and B. caribbaeus venoms [97]. 
Table 1. Proportions of protein families targeting hemostasis in Bothrops venom.

\begin{tabular}{|c|c|c|c|c|c|c|}
\hline Species & B. atrox & B. asper & B. jararaca & B. erythromelas & B. lanceolatus & B. caribbaeus \\
\hline $\begin{array}{c}\text { Snake venom } \\
\text { metalloproteinases (SVMP) }\end{array}$ & $25.8-85.0$ & $30.7-47.4$ & $10.0-64.0$ & $32.5-59.9$ & $42.4-74.2$ & 68.6 \\
\hline PI-SVMP & $4.6-65$ & $13.9-35.1$ & $3.6-10.4$ & $2.7-14.4$ & 25.8 & 30.6 \\
\hline PII-SVMP & $4.0-5.2$ & $<0.1-3.9$ & - & - & - & - \\
\hline PIII-SVMP & $3.1-69$ & $8.2-19.8$ & $6.7-25.2$ & $29.8-45.5$ & 48.4 & 38.0 \\
\hline $\begin{array}{c}\text { Snake venom serine } \\
\text { proteases }\end{array}$ & $0.5-21.5$ & $4.4-18.2$ & $3.0-36.0$ & $4.0-9.7$ & $14.4-27.4$ & 4.7 \\
\hline Phospholipases $\mathrm{A}_{2}$ & $4.2-48.0$ & $0.4-45.5$ & $<0.1-20.2$ & $8.1-15.1$ & $4.5-8.6$ & 12.8 \\
\hline L-amino acid oxydases & $0.5-16.9$ & $1.1-9.2$ & $<0.1-9.7$ & & $2.8-14.0$ & 8.4 \\
\hline Disintegrins & $<0.1-3.2$ & $<0.1-7.5$ & $0.2-7$ & $3.4-8.9$ & & 1.7 \\
\hline C-type lectin proteins & $0.4-13.1$ & $0.3-16.9$ & $9.0-36.0$ & $8.4-21.6$ & $<0.1-4.5$ & \\
\hline References & [99-103] & {$[104,105]$} & {$[98,106-108]$} & [109] & {$[97,98]$} & [97] \\
\hline
\end{tabular}

- , Ranges in the medical literature.

These contradictory results could be explained by an important intraspecific variability linked to different factors such as sex, geographical distribution, ontogeny and captivity.

Sex-based variation of $B$. atrox venom was observed even in siblings. Male venom showed higher LAAO, PLA 2 and hemorrhagic activities, while female venoms showed higher coagulant activity [103]. Venom from B. jararacussu males is more procoagulant than those of females [110].

A geographic and altitudinal venom variability was observed in B. asper lineages from North-Western South America, especially in the four major toxin families: SVMP (mainly PI- and PII-SVMP), PLA 2 , SVSP and CTL [105]. In the same way, Bothrops venezuelensis venoms, from five localities in the North-Central Venezuelan regions, showed differences in minimal hemorrhagic dose and fibrinolytic activity [111].

A linear relation between ontogenetic variability and snake size has been described in the venom composition of B. atrox, B. asper [112] and B. jararacussu [99]. Concentration of P-I SVMP is higher than that of P-III SVMP in the venom of adult specimens of B. asper, whereas venoms of neonates have a predominance of P-III SVMP [113]. In B. jararacussu venom, P-III-class SVMP with pro-coagulant and hemorrhagic functions were the most abundant components in venom of smaller snakes, while the basic myotoxic PLA $\mathrm{P}_{2}$ were the major components in larger snakes venoms [99]. Higher hematotoxicity confers more efficient predatory function in the venom from small snakes [112]. These proteomic differences have clinical consequences. Envenomings inflicted by adult B. atrox snakes cause more severe local inflammatory effects, whereas venom-induced coagulopathy is more frequent in envenomings caused by juvenile specimens [114]. Similarly, for an equal mass of venom from a small snake than a large one, more antivenom seems to be needed to correct coagulopathy [110].

Few studies reported modifications of the venom in snakes kept in captivity. The venom from $B$. atrox showed a weak variability restricted to the less abundant components in the majority of snakes. However, in some individuals, SVMPs were drastically affected showing the plasticity of the venom phenotype during the lifespan of snakes held in captivity for more than one year [115].

Intraspecies variation in snake venom has consequences on antivenom treatment because snakes of different sex, age or localities may be result in envenomation needing higher doses to achieve total neutralization of lethality or other toxic activities, in particular hemostatic ones $[110,116,117]$. Variation in the venom of snakes held in captivity raises the question of the effectiveness of antivenoms manufactured from these venoms [76]. However, it is likely that (a) pooling of venoms limits the spectrum of variability and (b) gene and demographic differences are more marked than variations in venoms occurring in captivity [107]. 


\section{Pathophysiology of Bleeding}

The main classes of toxins isolated from Bothrops venoms are endowed with multiple biological activities targeted against hemostasis (Table 2). A multimodal approach combining clinical, animal model-based and in vitro studies has allowed to understand the pathophysiology of bleeding and the respective role of each protein family involved.

Table 2. Points of hemostasis targeted by the different families of proteins isolated in Bothrops venoms.

\begin{tabular}{|c|c|c|c|c|}
\hline Protein Family & Vascular Effect & Platelet Effect & Coagulation Effect & Fibrinolysis Effect \\
\hline $\begin{array}{l}\text { Snake venom } \\
\text { metalloproteinases }\end{array}$ & Hemorrhage & $\begin{array}{c}\text { Aggregation } \\
\text { Inhibition of aggregation }\end{array}$ & $\begin{array}{c}\text { FII, FX activation } \\
\text { Fibrinogen degradation }\end{array}$ & $\begin{array}{l}\text { Fibrin degradation } \\
\text { Tissu-type plasminogen } \\
\text { activator activation } \\
\alpha_{2} \text {-antiplasmin } \\
\text { inhibition }\end{array}$ \\
\hline $\begin{array}{c}\text { Snake venom serine } \\
\text { proteases }\end{array}$ & & Aggregation & $\begin{array}{c}\text { FV, FVIII, FXIII } \\
\text { activation } \\
\text { Fibrinogen clotting } \\
\text { Fibrinogen degradation }\end{array}$ & $\begin{array}{c}\text { Fibrin degradation } \\
\text { PAI- } 1 \text { and } \\
\alpha_{2} \text {-antiplasmin } \\
\text { inhibition }\end{array}$ \\
\hline Phospholipases $\mathrm{A}_{2}$ & Hemorrhage & $\begin{array}{c}\text { Aggregation } \\
\text { Inhibition of aggregation }\end{array}$ & & \\
\hline L-amino acid oxydases & & $\begin{array}{c}\text { Aggregation } \\
\text { Inhibition of aggregation }\end{array}$ & & \\
\hline Disintegrins & & Inhibition of aggregation & & \\
\hline C-type lectin proteins & & $\begin{array}{c}\text { Aggregation } \\
\text { Inhibition of aggregation }\end{array}$ & $\begin{array}{c}\text { FIX, FX, FIIa, Protein S } \\
\text { inhibition }\end{array}$ & \\
\hline
\end{tabular}

\subsection{Vascular Damage}

In patients envenomed by Bothrops, systemic bleeding can occur even with clottable blood and normal platelet counts, suggesting than venom-induced vascular damage is primarily responsible for the bleeding $[29,45]$.

In an intravital microscopic observation of the hemorrhage process induced by $B$. asper venom on the mouse cremaster muscle, bleeding started from the capillary segment of the microvasculature, about $5 \mathrm{~min}$ after venom exposure. It was explosive, appearing as rapid bursts of erythrocytes into the extravascular space [118]. Similar results were observed with B. jararaca venom [119].

Hemorrhage happened per rhexis (erythrocytes escape through gaps in damaged endothelial cells) and not per diapedesis (through widened intercellular junctions) [120]. In mice, the intramuscularly injection of whole $B$. asper venom induced endothelial cell degeneration in $1 \mathrm{~min}$. On electron microscopy, the morphological pattern of vascular damage associated a reduction in the thickness of endothelial cells with blebs and cytoplasmic projections protruding to the vascular lumen, a decrease in the number of pinocytotic vesicles and a detachment of some endothelial cells from their surrounding basal lamina, leading to gaps in the continuity of endothelial cells then extravasation. No alterations in the intercellular junctions were observed in damaged capillaries [120].

All Bothrops venoms including B. lanceolatus and B. caribbaeus ones have hemorrhagic activity (Table 3). 
Table 3. Lethal and hemostatic activities of Bothrops venoms.

\begin{tabular}{|c|c|c|c|c|c|}
\hline Species & B. atrox & B. asper & B. jararaca & B. lanceolatus & B. caribbaeus \\
\hline $\begin{array}{l}\text { Median lethal activity (LD50) } \\
(\mu \mathrm{g} / \mathrm{g})^{1}\end{array}$ & $3.89-4.75$ (ip) & $3.39-3.79$ (ip) & $1.89-2.125$ (ip) & 6 (iv)/12.8 (ip) & 3 (iv)/7.5 (ip) \\
\hline $\begin{array}{l}\text { Local minimum hemorrhagic } \\
\text { dose (MHD) }(\mu \mathrm{g})^{2}\end{array}$ & $1.4-2.4$ & $0.8-1.5$ & 0.26 & $3.6-3.7$ & 0.7 \\
\hline $\begin{array}{c}\text { Minimum coagulant } \\
\text { concentration }(\mathrm{MCC})(\mu \mathrm{g} / \mathrm{mL})^{3}\end{array}$ & $0.8-3$ & $0.32-1$ & 0.54 & NA & NA \\
\hline $\begin{array}{l}\text { Minimum defibrinating dose } \\
(\mathrm{MDD})(\mu \mathrm{g})^{4}\end{array}$ & $1.7-5$ & $3-5$ & 3.3 & NA & NA \\
\hline References & {$[121,122]$} & {$[121,122]$} & [122] & {$[121,123]$} & [97] \\
\hline
\end{tabular}

${ }^{1}$ Venom dose which induces lethality in $50 \%$ of mice injected by intraperitoneal (ip) or intravenous (iv) injection. ${ }^{2}$ Lowest venom dose which induces a hemorrhagic area of $10 \mathrm{~mm}$ diameter, $2 \mathrm{~h}$ after intradermal injection in mice. ${ }^{3}$ Lowest venom concentration which induces coagulation of citrated human plasma in $60 \mathrm{~s} .{ }^{4}$ Lowest venom dose, which induces defibrination in mice $1 \mathrm{~h}$ after intravenous injection. NA: no activity detected at the highest venom dose tested.

\subsubsection{Degradation of Basement Membrane by SVMP}

Serum SVMP levels are significantly higher in patients with systemic bleeding compared to those without bleeding in B. jararaca envenomation [52]. In experimental murine model, acute vascular damaging effects observed with $B$. asper whole venom were also induced by BaP1 (P-I SVMP) and BaH-1 (P-III SVMP) from B. asper venom, suggesting that SVMP have an important role in bleeding $[124,125]$. When the peptidomimetic matrix metalloproteinase inhibitor batimastat and the chelating agent $\mathrm{CaNa}_{2}$ EDTA were administered at various time intervals after experimental envenoming in mice at the same site of $B$. asper venom injection, both compounds effectively neutralized local hemorrhage [126]. This highlights the importance of the metalloproteinase-related catalytic activity as major mechanism involved in bleeding.

The ability of SVMP able to induce hemorrhage, named hemorrhagins, is not related to a direct cytotoxic effect on capillary endothelium and the rapid degenerative changes of endothelial cells observed in vivo are the result of the proteolytic degradation of basement membrane (BM) components of microvessels [124,127]. SVMP are able to degrade diverse components such as types I and IV collagen, fibronectin and laminin once incubated with these extracellular matrix proteins in vitro [124,128]. On human umbilical-vein endothelial cell culture, jararhagin decreased endothelial cell viability in a concentrationdependent manner and induced cellular apoptosis, probably due to a catalytic activity suggestive of anoikis, by loss of contact with their matrix [85,129]. Degradation of BM and its related extracellular matrix components by P-III SVMP and P-I SVMP was confirmed in vivo [130-132]. SVMP involved in disruption of BM also play an important role in the development of coagulopathy following the rapid venom coagulation component spread from the injected area into the systemic circulation [133].

The proteomic analysis of exudates collected in the vicinity of damaged gastrocnemius muscle of mice showed the early presence of BM components and other extracellular matrix proteins reflecting the rapid microvascular damage induced by SVMP. Presence of fragments of type IV collagen and perlecan one hour after envenoming suggests that hydrolysis of these BM components plays a key role in the genesis of hemorrhage [134]. When comparing the action of P-I hemorrhagic and non-hemorrhagic SVMP (respectively $\mathrm{BaP1}$ and leuc-a from B. leucurus venom), a striking difference was noticed regarding the hydrolysis of type IV collagen [132], suggesting the prominent role that this collagen plays in the mechanical stability of BM and the capillary wall. In vivo studies indicated that hydrolysis of collagen IV by mainly P-II and P-III SVMP is crucial in destabilizing microvessel structures and causing hemorrhage [135].

P-II and P-III SVMP bind more specifically to capillary BM than P-I SVMP, owing to the presence of exosites in the disintegrin, disintegrin-like and cysteine-rich domains of these SVMP, thus explaining their generally higher hemorrhagic activity $[135,136]$. Collagen 
binding through a motif located in the disintegrin subdomain allows accumulation of jararhagin P-III SVMP at the site of injection, close to capillary vessels, where its catalytic activity leads to a local hemorrhage [137].

However, the presence of non-catalytic domains in the SVMP is not essential for hemorrhagic activity. Atroxlysin-Ia, a P-I SVMP from B. atrox venom, has a high hydrolytic activity towards extracellular matrix proteins, including laminin and collagen IV and is able to cause a fast disruption of capillary vessels allowing the induction of hemorrhage similar to those induced by Batroxrhagin, a P-III SVMP isolated from the venom of the same species [138].

$\mathrm{PLA}_{2}$ may participate in bleeding, by increasing the activity of SVMP. For example, a $\mathrm{PLA}_{2}$ from $B$. alternatus venom exhibits no toxicity towards endothelial cells in culture but was found to significantly enhance the detaching activity of balteragin, a hemorrhagic P-III SVMP from the same venom, on endothelial cells [139].

\subsubsection{Consequences on the Endothelium}

In vitro BM proteins hydrolysis occurred at relatively late time intervals, whereas in vivo hemorrhage developed within minutes of injection [27]. This difference was explained by a "two-step" mechanism. First, hemorrhagic SVMP hydrolyze capillary BM proteins, then hydrostatic pressure and tangential shear stress induce the distention of the capillary wall, resulting in the disruption of endothelial cell integrity and the consequent hemorrhage [140]. Moreover, in experimental conditions, when blood flow was interrupted, no endothelial cell pathology was observed, suggesting that blood flow is essential for a rapid Bothrops envenoming-related endotheliopathy [140].

Despite the absence of direct toxicity, Bothrops venoms induce endothelial injury which may participate to bleeding. Important increase in plasma soluble thrombomodulin level was reported indicating severe endothelial injury after the intravenous injection of $B$. jararaca venom in rabbits [141]. High levels of soluble thrombomodulin in plasma may favor hemorrhage, due its cofactor activity in the thrombin-mediated activation of protein $\mathrm{C}$ and initiation of a profibrinolytic way [142]. Elevation of soluble thrombomodulin due to the crude venom was totally suppressed by pretreatment with heparin, suggesting that endothelial cell injury caused by B. jararaca venom is not due to the direct toxicity of SVMP but to thrombin activated by venom [141].

Hemorrhagic Factor 3 (HF3), a hemorrhagic P-III class SVMP from B. jararaca venom, cleaves in vivo endothelial glycocalyx proteoglycans such as biglycan, decorin, glypican-1, lumican and syndecan-1, participating to the disruption of microvasculature integrity and contributing to hemorrhage [143].

\subsection{Platelet Impairments}

\subsubsection{Thrombocytopenia}

In mice, a dose-dependent drop in the number of platelets was observed after the intravenous injection of $B$. asper venom [144]. B. jararaca venom directly aggregated washed human and mouse platelets in vitro and stimulated secretion of adenosine triphosphate (ATP), platelet factor 4 (PF4) and $\beta$-hexosaminidase, which are present in dense granules, alpha granules and lysosomes of platelets, respectively [145].

Thrombocytopenia may be due to different groups of toxins from Bothrops venoms. Clinical studies establishing an inverse correlation between platelet count and hemorrhagin level suggested a link between thrombocytopenia and SVMP activity [52]. Hemorrhagic P-III SVMP was shown to contribute to thrombocytopenia since intravenous injection of jararhagin reduced platelet count in a mouse model of Bothrops envenomation [144]. Reduction of platelet number was explained by their activation, aggregation and sequestration in response to the extensive blood vessel damage and the intravascular thrombin generation due to SVMP [144]. Moojenactivase, a P-III SVMP from B. moojeni venom, induced direct and thrombin-mediated platelet aggregation [146]. However, thrombocytopenia was under 
the influence of mechanisms not depending on intravascular generation of thrombin such as observed with SVMP [147].

Thrombocytin and Platelet-aggregating proteinase (PA-BJ), SVSP isolated from the venom of $B$. atrox and B. jararaca respectively, induce platelet aggregation and granule secretion without clotting fibrinogen. Both enzymes induced calcium mobilization in platelets, and cleaved the protease-activated receptor (PAR)1-receptor [148]. Bothrombin from $B$. jararaca venom activate platelets by interacting with GPIb which is a thrombin receptor [149].

Mild thrombocytopenia was observed in patients with either incoagulable or coagulable blood, suggesting an independent mechanism from procoagulant toxins [45]. Bothrocetin from B. jararaca venom and Aspercetin from B. asper venom induced platelet aggregation in the presence of $\mathrm{vWF}$, promoting its interaction with platelet receptor $\mathrm{GPIb}$ and leading to thrombocytopenia and prolonging the bleeding time in mice $[150,151]$. These C-type lectin-like proteins, by reducing platelet numbers, promoted hemorrhagic lesions initiated by SVMP [150].

Bothrops $\mathrm{PLA}_{2}$ are able to induce platelet aggregation such as bothropstoxin-II, an Asp49 PLA $_{2}$ isolated from B. jararacussu venom [152]. The ability of $\mathrm{PLA}_{2}$ to induce platelet activation is related to the capacity to hydrolyse phophatidylcholine and the liberation of arachidonic acid [153]. BmooLAAO-I, a LAAO from B. moojeni venom induces platelet aggregation although the exact underlying mechanisms are not well understood [154].

\subsubsection{Platelet Hypoaggregation}

Besides thrombocytopenia, Bothrops venom may induce qualitative thrombopathy. In a work studying platelet function during human envenomations by $B$. jararaca, most of patients who presented systemic bleeding showed hypoaggregation to ADP, ristocetin and collagen [46].

Basparin A, a prothrombin activator P-III SVMP from B. asper venom and jararacussinI, a TLE SVSP from B. jararacussu venom, induced hypoaggregation to ADP in a mouse model. It was suggested that the hypoaggregating effect depends on defibrin(ogen)ation, because fibrinogen is needed for interaction with integrin $\alpha \mathrm{Ilb} \beta 3$ or because the fibrin(ogen) degradation products generated interact and block this integrin receptor [144]. A phosphodiesterase from $B$. jararaca venom, NPP-BJ, is a homodimeric glycoprotein inhibiting platelet aggregation induced by ADP, by hydrolysis of adenylated nucleotides secreted from platelet dense bodies during platelet activation. Polyclonal antibodies raised against this phosphodiesterase could not abolish the lethal activity of $B$. jararaca venom, suggesting a minor contribution to the lethality [155].

The inhibition of ristocetin-induced aggregation has been observed with jararhagin and was attributed to a direct effect on vWF rather than to its action on the GP Ib-IX-V receptor. Jararhagin degrades $\mathrm{vWF}$, in particular the portion of the molecule, which contains the ligand site for the GPIb receptor, the A1 domain [156]. Mutimeric analysis of plasma incubated with $B$. jararaca venom in vitro shown a marked degradation of vWF with loss of high and intermediate molecular weight bands and an increase in low molecular weight fragments, but these results were much less obvious in patients envenomed by this species [45].

In contrast, collagen-induced platelet aggregation is inhibited by jararhagin following its binding to the $\alpha_{2}$-subunit I domain of the platelet surface $\alpha_{2} \beta_{1}$ integrin (collagen receptor) [157]. Jararhagin also cleaves the $\beta_{1}$ subunit of the same integrin [156]. This inhibition was initially supposed to be linked to the interaction of sequences present in Dislike and Cys-rich domains of P-III SVM with integrin $\alpha_{2} \beta_{1}$, because this effect is not related to P-I SVMP which lack such sequences [64]. Basparin A also inhibits collagen-dependent platelet aggregation in vitro [158]. In mice, this effect is abolished by batimastat, indicating its dependence on the enzymatic activity and not on the effect of the disintegrin-like and cysteine-rich domains of this protein $[144,159]$. 
Some PLA 2 inhibit platelet aggregation such as BJ- PLA 2 from B. jararaca [160], BthA-I$\mathrm{PLA}_{2}$ from B. jararacussu [161], BmooTX-I [162] and Bmoo PLA 2 [163] from B. moojeni and BE-I- PLA $A_{2}$ from $B$. erythromelas [164]. The inhibition of platelet aggregation by $\mathrm{PLA}_{2}$ is due to the cleavage of the by-products of arachidonic acid [91].

Bl-LAAO from B. leucurus venom dose-dependently inhibited platelet aggregation of both human platelet-rich plasma (PRP) and washed platelets [165].

\subsection{Venom-Induced Consumption Coagulopathy}

Crude venoms exhibit strong procoagulant effects in dose-dependent manner in vitro $[110,117,166,167]$. Study of Bothrops venoms by thromboelastographic method in human plasma showed a predominantly procoagulant activity with an increase in coagulation speed and of clot growth velocity [168]. This pathological activation of coagulation leads to incoagulability and defibrin(ogen)ating in vivo by consuming the limited amounts of clotting factors physiologically available following their continuous activation and/or degradation [144,158].

\subsubsection{Coagulation Factor Activators}

SVMP are able to clot citrated plasma by activating prothrombin and/or factor X. P-I SVMP (like bothrojaractivase from B. jararaca venom) and P-III SVMP (like basparin A) activate prothrombin to $\alpha$-thrombin by producing meizothrombin without requiring additional cofactors such as calcium or phospholipids, which ranks them in the group A of snake venom prothrombin activators $[158,169,170]$. Prothrombin activators found in species other than Bothrops spp. are distinguishable from group B (SVMP with a calciumdependent activity), group C (SVSP similar to factor Xa-factor/Va complex) and group D (SVSP similar to factor Xa). Group B prothrombin activators convert prothrombin to meizothrombin while groups $C$ and $D$ prothrombin activators convert prothrombin to mature thrombin [171]. In addition to cleaving the heavy chain of factor $X$ that results in its activation like with its physiological activators, TF-VIIa and VIIIa-IXa, factor X alpha activators 1 and 2 from $B$. atrox venom produce two other cleavages, i.e., one near the $\mathrm{N}$ terminal end of the heavy chain of factor $X$, generating factor $X \mathrm{mu}$ and a second located at one extremity of the heavy chain of factor Xa alpha, generating factor Xav [172]. The SVMP moojenactivase induces human plasma clotting in vitro by activating coagulation factors II (prothrombin) and $X$, which in turn generate $\alpha$-thrombin and factor Xa, respectively [146].

Thrombocytin, a SVSP isolated from B. atrox venom, activates factors V, VIII and XIII $[173,174]$. Activation of factor V by thrombocytin proceeds via the cleavage of two peptide bonds yielding a product similar to thrombin-activated factor $V$ [174].

Activation of these factors by venom leads to generate endogenous thrombin in vitro, even without the addition of TF as a trigger [175]. Thus snakebite-related coagulopathy should be distinct from the usual disseminated intravascular coagulopathy due to a thrombin generation mediated by the TF/VIIa pathway [176].

\subsubsection{Thrombine-Like Enzymes}

Defibrination also depends on the action of thrombine-like enzymes which directly hydrolyze fibrinogen in fibrin and induce in vitro clotting of fibrinogen solution. Despite their name, TLE show less than $40 \%$ similarity with human thrombin [177]. They preferentially release either fibrinopeptide A or B, rarely both with equal efficiency, unlike thrombin. Moreover, TLE do not activate other coagulation factors, especially factor XIII, leading to friable clots without crosslinking of fibrin, readily degraded by plasmin. Finally TLE are not inhibited by thrombin inhibitors such as antithrombin, heparin and hirudin [178].

BjussuSP-I, from B. jararacussu, induce defibrin(ogen)ation if intravenously or intramuscularly administered, with reduction in plasma fibrinogen concentration. When injected with SVMP BaP1, BjussuSP-I induced a slightly larger hemorrhagic lesion in the skin of mice, suggesting local hemorrhagic activity exacerbation induced by hemorrhagic SVMP [179]. Experiments performed with inhibitors of metalloproteinases and 
serine proteinases clearly evidenced that SVMP are by far the most important in vitro procoagulant and in vivo defibrin(ogen)ating components in Bothrops venom, whereas the TLE play a minor role, probably due to the low content of the latter enzyme in these venoms $[64,113,144,147,180]$.

\subsubsection{Anticoagulant Toxins}

Bothrojaracin I, a CTL purified from B. jararaca venom, inhibits $\alpha$-thrombin by the non-covalent binding to exosites 1 and 2, decreases the binding of $\alpha$-thrombin to fibrinogen and thrombomodulin and reduces protein $C$ and prothrombin activation [181,182].

An anticoagulant C-type lectin isolated in B. jararaca venom is able to inhibit factors IX and $X$ and protein $S$ in a calcium-dependent fashion [183].

\subsection{Fibrinogenolysis and Fibrinolysis \\ 4.4.1. Primary Fibrin(ogen)olysis}

Non-coagulant proteinases having fibrin(ogen)olytic activity may contribute to fibrinogen consumption without conversion to fibrin. P-I SVMP have direct fibrin(ogen)olytic activity. Their main biological substrate is fibrin(ogen), whose $A \alpha$-chain is degraded rapidly and independently of activation of plasminogen. They are termed as $\alpha$-fibrinogenases, but the other chains of fibrinogen can be substantially degraded during time [79]. For example, Batx-I, from Colombian B. atrox venom, is a P-I SVMP degrading preferentially the A $\alpha$ and $B \beta$-chains, but also inducing a partial degradation of the $\gamma$-chain [184].

Hemorrhagic P-III SVMP may take part to the consumption of clotting factors. Jararaghin cleaves fibrinogen in the $\mathrm{C}$-terminal part of the $\mathrm{A} \alpha$ chains, resulting in the removal of a $23 \mathrm{kDa}$ fragment while $\beta$ and $\gamma$ chains remain unaffected. The remaining purified fibrinogen molecule is still fully functional in both platelet aggregation responses to ADP and in its ability to clot plasma by activating thrombin. The only consequence of the $\alpha$-fibrinogenase activity of jararhagin was abnormal fibrin polymerization by thrombin [185]. In vitro, purified jararhagin induces strong fibrinolytic activity in human and different animal plasmas [186].

SVSP can exhibit fibrin(ogen)olytic without thrombine-like activity. For example, BjSP from $B$. jararaca venom cleave the $A \alpha$ - and $B \beta$-chains of fibrinogen without forming fibrin clots [187]. BjussuSP-I, a TLE SVSP from B. jararacussu venom, has a primary fibrinolytic activity [188].

\subsubsection{Secondary Fibrinolysis}

Hyperfibrinolysis can also contribute to fibrinogen and fibrin consumption [48]. In mice, the intravenous injection of SVMP (basparin A) or SVSP (BjussuSP-I and jararacussin-I) induced secondary fibrinolysis, marked by the post-injection increase in fibrin degradation products and D-dimers [144,158,179].

In guinea-pig, plasma, purified jararhagin increases tPA activity by causing dissociation of the tPA/PAI- 1 complex and promotes fibrinolysis by the inactivation of $\alpha_{2}$-AP [186]. Reptilase, a TLE from B. jararaca venom, inactivates two fibrinolysis inhibitors, PAI- 1 and $\alpha_{2}-\mathrm{AP}$, and thus induces fibrinolysis pathway [189].

\section{Pathophysiology of Thrombosis}

\subsection{Prothrombotic State Induced by Bothrops Venoms}

As stated previously, toxins responsible for platelet aggregation and coagulation activation lead to platelet and coagulation factor consumption, thus promoting bleeding. However, this initial thrombogenic state may cause microthrombi. An in vivo study of local tissue damage after the topical administration of $B$. asper venom on the mouse cremaster muscle showed the formation of thrombi and emboli in veinules, not in arterioles, before the onset of bleedings [118]. Similar results were reported with B. jararaca venom [119]. After the intramuscularly injection of B. asper venom in mice, numerous capillaries were damaged with platelet aggregates and fibrin deposition in their lumen [120]. The intramuscular injection of $B$. jararacussu and B. insularis venoms induced vascular occlusive thrombosis 
besides hemorrhage, suggesting that ischemia contributed to muscle necrosis $[190,191]$. In one rat model, the intravenous administration of $B$. jararaca venom combined with stasis of inferior vena cava resulted in venous thrombosis [192,193] while, in another rat model with venom-induced AKI, its administration resulted in intravascular hemolysis and massive fibrin deposition in glomerular capillaries [194]. Based on all these findings, this prothrombotic state appears in relation to multiple factors such as phenotypic switch of endothelial cells, platelet aggregates and hypercoagulability.

\subsubsection{TF Surexpression and Endotheliopathy}

The intravenous or subcutaneous injection of $B$. jararaca venom in rats increased the activity and expression of TF at the site of venom injection as well as in plasma and lungs [180]. Berythractivase, a P-III SVMP isolated from B. erythromelas venom, was demonstrated in vitro to render endothelial cells highly thrombogenic, with releasing of vWF and expression of TF, ICAM-1 and E-selectin [195,196]. Endothelial biomarkers, such as VCAM-1 and angiopoietin-1, may be clinically useful as predictors of Bothrops venomrelated AKI [197]. Moojenactivase, a P-IIId SVMP owing CTL domain isolated from $B$. moojeni venom, induces a procoagulant behavior in peripheral blood mononuclear cells by increasing TF in vitro $[146,198]$.

\subsubsection{Platelet Aggregates and Hypercoagulability}

Bothrocetin has been found to induce platelet aggregates and microthrombi in the lung and spleen [199]. Similarly, aspercetin induced the formation of platelet aggregates in the lung microvessels of mice [144]. The intraperitoneal injection of bothrocetin to rats was shown to induce thrombotic thrombocytopenia with vWF depletion The almost total disappearance of intermediate and high molecular weight multimers of vWF, then the recovery of vWF and platelet count was associated with the observation in plasma of unusually large forms of vWF multimers [199].

Once bound to fibrin the capacity of batroxobin, a TLE from B. atrox venom, to promote fibrin accretion was found 18 -fold greater than that of thrombin, that may promote microvascular thrombosis and fibrin deposition [200,201].

In a rat model of $B$. jararaca envenomation, TMA was reported with thrombocytopenia, hemolytic anemia, schizocytes and microcytes [147]. The onset of microangiopathic hemolytic anemia was dependent on thrombin generation induced by SVMP, since pretreatment of animals with warfarin, an inhibitor of synthesis of vitamin K-dependent coagulation factors, could prevent it. These results indicated that, at least in this species, thrombin generation followed by fibrin formation and deposition in the vascular bed are involved in TMA pathogenesis.

The intravenous injection of moojenactivase induced intravascular hemolysis and red blood cell fragmentation, and microthrombi in small vessels in lungs then hemorrhage in rats. The local ischemia at the injection site seemed due to abundant thrombi formation since this SVMP did not provoke vessel disruption and local hemorrhage [198]. At low doses injected intravenously or intramuscularly to mice, Basparin A only induced defibrin(ogen)ation. At higher doses, its intravenous administration was responsible for numerous occluding thrombi in pulmonary vessels, mainly in arteries and arterioles, leading to rapid death [158].

To date, determinants leading to a hemorrhagic or thrombotic phenotype during envenomation remain unknown. Interestingly, patients with TMA did not experience systemic bleeding. Likewise, P-III SVMP such as berythractivase, moojenactivase or basparin A, able of inducing systemic thrombi, are devoid of hemorrhagic activity $[129,158,198]$, suggesting that situations at lower risk of bleeding may favor thrombotic complication onset.

\subsection{Macrothrombosis during Envenomation by B. lanceolatus and B. caribbaeus}

The exact mechanism of macrothrombosis in human envenomation by B. lanceolatus and $B$. caribbaeus remains unknown. There is not successful animal model describing the 
thrombotic manifestation with one of these two species [97,202], suggesting a speciesspecific effect and making it difficult to understand thrombotic mechanisms.

\subsubsection{Lack of Proaggregating or Procoagulant Activity of B. lanceolatus Venom}

Both crude B. caribbaeus venom and isolated snaclec from these venoms induce platelet aggregation and agglutination in human PRP. The snaclec binds directly to glycoprotein $\mathrm{Ib}(\mathrm{GPIb})$ without platelet activation and induces agglutination in washed fixed platelets without requiring vWF, contrary to botrocetin or aspercetin [202]. Despite venom-induced thrombocytopenia in mice, $B$. lanceolatus venom had no direct effect on platelet aggregation in human PRP $[97,123]$.

Unlike B. atrox, B. asper and B. jararaca, B. lanceolatus and B. caribbaeus venoms were not coagulant when tested on human citrated plasma (Table 3), suggesting the absence of prothrombin or factor $\mathrm{X}$ activators $[97,121,123]$. Of note, these studies examined the coagulation of citrated plasma without adding calcium and phospholipids while it has been shown that these co-factors sometimes conditioned the level of procoagulant activity of Bothrops toxins $[117,166]$. B. lanceolatus venom dose-dependently clotted purified human fibrinogen, indicating the presence of a thrombine-like enzyme [203] but was devoid of defibrinating activity after intravenous injection in mice [97,121,123].

Intravenous injection of $B$. caribbaeus venom induced a degradation of fibrinogen with an increment in FDP levels but without an increase in D-dimer levels, suggesting more a fibrinogenolytic activity without thrombosis in mice than a fibrinolysis shutdown [202]. Thus, to our knowledge, no toxin responsible for platelet aggregation or hypercoagulability has not been identified in the venom of B. lanceolatus.

\subsubsection{A TMA-Type Mechanism?}

The fatal case of B. lanceolatus bite reported by Malbranque et al. supported a TMAtype mechanism of injuries [60]. Histopathologic examination showed multi-focal TMA with endothelial-medial dissection by fibrinous thrombi extending from foci of endothelial damage in small arteries and arterioles of brain, heart, lungs, intestine and kidneys. In addition, there was an unusually intense angiogenesis in cerebral infarcts. There was no vasculitis, perivasculitis or perivascular hemorrhage. Occlusive microthrombi were composed of endothelial cellular debris, platelets and fibrin.

The main TMA-related diseases are thrombotic thrombocytopenic purpura (TTP) and hemolytic uremic syndrome (HUS) [204]. TTP is caused by the increase of highly reactive high molecular weight multimers of vWF caused by deficiency of the specific vWF-cleaving protease ADAMTS13 [205]. Such mechanism is unlikely here as ADAMTS13 activity is most often preserved in patients bitten by B. lanceolatus (communication from Dr Joly, French reference laboratory of TMA, Lariboisière Hospital).

In typical HUS, endothelial activation is induced by a microbial toxin called Shiga toxin, causing a cytotoxic, proapoptotic and prothrombotic phenotype of the endothelial cell, with increased TF expression, vWF release and platelet activation. By contrast, typical HUS is caused by the complement system activation leading to terminal complement complex formation [206].

Venoms of B. lanceolatus and B. caribbaeus have vascular toxicity. Their intravenous administration induced lung hemorrhage in mice, suggesting the involvement of hemorrhagic SVMP $[97,123,202]$. Their intramuscular injection in the gastrocnemius muscle induced prominent hemorrhage [97,123]. A hemorrhagic P-I SVMP was isolated in B. lanceolatus venom [207] while a P-III SVMP was isolated in B. caribbaeus venom [202].

However, the absence of increments in plasma sE-selectin levels suggested the lack of endothelial cell damage after the intravenous B. caribbaeus venom injection in mice [202]. Similarly, B. lanceolatus venom showed low gelatinolysis activity and probably lacking activity on critical extracellular matrix proteins, which degradation is associated with hemorrhage [98]. B. lanceolatus venom showed particularly low toxicity in endothelial cells (EAhy926) compared to B. jararaca venom. After $24 \mathrm{~h}$ of exposure, B. lanceolatus venom 
appeared about 10 times less toxic than $B$. jararaca venom, while longer times of incubation enhanced $B$. lanceolatus venom cytotoxicity. B. lanceolatus venom did not induce adhesion molecules expression such as ICAM-1, VCAM-1 or E-selectin, neither TF expression on vascular endothelial cell membranes [208].

Thus, based on these experimental findings, B. lanceolatus venom seems to exhibit poor direct endothelial cell toxicity, suggesting the involvement of an intermediate system able to activate endothelium in vivo. The complement system may induce thrombosis by activating endothelial cells, with the production of C5a and terminal complement complex triggering TF expression $[209,210]$. B. lanceolatus venom can activate all three complement-pathways. In an ex vivo human blood assay, this venom strongly induced the generation of anaphylatoxins, such as $\mathrm{C} 3 \mathrm{a}, \mathrm{C} 4 \mathrm{a}, \mathrm{C} 5 \mathrm{a}$ and the soluble terminal complement complex [211,212]. Venoms from numerous other species from the genus Bothrops are able to activate the complement system by one or several activation pathways, generating high quantities of anaphylatoxins by directly cleaving $\mathrm{C} 3$ and $\mathrm{C} 5$ or by inactivating the regulator C1-INH. These events involved both metalloproteases and serine proteases [213].

\section{Conclusions: Between Scylla and Charybdis}

Bothrops venoms are endowed with multiple activities on hemostasis, responsible for different clinical manifestations, ranging from local bleeding to thrombosis and/or systemic bleeding. It has been clearly established that bleeding is not due to disseminated intravascular coagulopathy but to the direct multifocal toxicity involving the vessels, platelets and coagulation. Compared to bleeding, microthrombosis is rarely reported in Bothrops envenomation. Fibrin deposition induced by venom-related hemostasis disorders seems at least initially not to result in clinical impact. However, the high incidence of further complications such as AKI suggests a larger involvement of hemostasis disorders than initially believed. In some situations, thrombi may lead to TMA. Case reports and experimental studies suggest that thrombosis involvement is more important when hemorrhage is absent and coagulopathy rapidly corrected. This paradoxical observation requires vigilance even in mild-to-moderate envenomation presentations.

Mechanisms responsible for thrombosis during B. lanceolatus envenomation are not fully understood. Endothelial damage seems the most likely involved basis. Due to weak venom activity on vessels, the suggested involvement of the complement system based on in vitro studies merits further investigation in vivo.

The relatively similar composition of the different Bothrops venoms suggests that bleeding and thrombosis should not be considered as two different pathologies but rather two sides of the same pathophysiological continuum. Factors predisposing to envenomation with rather hemorrhagic versus thrombotic phenotype are unknown. Their identification would allow better understanding hemostasis disorders induced by venoms from a dynamic perspective and thus anticipating their onset when managing a bitten patient.

Author Contributions: Conceptualization, S.L. and B.M.; investigation, S.L., J.-P.C., L.C., S.M., D.R., V.S. and B.M.; writing—original draft preparation, S.L.; writing—review and editing, J.-P.C. and B.M. All authors have read and agreed to the published version of the manuscript.

Funding: This research received no external funding.

Conflicts of Interest: The authors declare no conflict of interest.

\section{References}

1. Magalhães, S.F.V.; Peixoto, H.M.; Moura, N.; Monteiro, W.M.; de Oliveira, M.R.F. Snakebite envenomation in the brazilian amazon: A descriptive study. Trans. R. Soc. Trop. Med. Hyg. 2019, 113, 143-151. [CrossRef]

2. Roriz, K.R.P.S.; Zaqueo, K.D.; Setubal, S.S.; Katsuragawa, T.H.; Silva, R.R.D.; Fernandes, C.F.C.; Cardoso, L.A.P.; Rodrigues, M.M.S.; Soares, A.M.; Stábeli, R.G.; et al. Epidemiological study of snakebite cases in brazilian western amazonia. Rev. Soc. Bras. Med. Trop. 2018, 51, 338-346. [CrossRef]

3. Costa, M.K.B.D.; Fonseca, C.S.D.; Navoni, J.A.; Freire, E.M.X. Snakebite accidents in rio grande do norte state, Brazil: Epidemiology, health management and influence of the environmental scenario. Trop. Med. Int. Health 2019, 24, 432-441. [CrossRef] 
4. Chippaux, J.-P. Epidemiology of envenomations by terrestrial venomous animals in Brazil based on case reporting: From obvious facts to contingencies. J. Venom. Anim. Toxins Incl. Trop. Dis. 2015, 21, 1-17. [CrossRef]

5. Da Silva Souza, A.; de Almeida Gonçalves Sachett, J.; Alcântara, J.A.; Freire, M.; Alecrim, M.D.G.C.; Lacerda, M.; de Lima Ferreira, L.C.; Fan, H.W.; de Souza Sampaio, V.; Monteiro, W.M. Snakebites as cause of deaths in the western Brazilian Amazon: Why and who dies? deaths from snakebites in the Amazon. Toxicon 2018, 145, 15-24. [CrossRef]

6. González-Andrade, F.; Chippaux, J.-P. Snake Bite Envenomation in Ecuador. Trans. R. Soc. Trop. Med. Hyg. 2010, 104, 588-591. [CrossRef]

7. Mutricy, R.; Heckmann, X.; Douine, M.; Marty, C.; Jolivet, A.; Lambert, V.; Perotti, F.; Boels, D.; Larréché, S.; Chippaux, J.-P.; et al. High mortality due to snakebites in French Guiana: Time has come to re-evaluate medical management protocols. PLoS Negl. Trop. Dis. 2018, 12, e0006482. [CrossRef] [PubMed]

8. Sevilla-Sánchez, M.J.; Mora-Obando, D.; Calderón, J.J.; Guerrero-Vargas, J.A.; Ayerbe-González, S. Snakebite in the department of Nariño, Colombia: A retrospective analysis, 2008-2017. Biomedica 2019, 39, 715-736. [CrossRef] [PubMed]

9. Dolab, J.A.; de Roodt, A.R.; de Titto, E.H.; García, S.I.; Funes, R.; Salomón, O.D.; Chippaux, J.-P. Epidemiology of snakebite and use of antivenom in Argentina. Trans. R. Soc. Trop. Med. Hyg. 2014, 108, 269-276. [CrossRef] [PubMed]

10. Fernández, P.; Gutiérrez, J.M. Mortality due to snakebite envenomation in Costa Rica (1993-2006). Toxicon 2008, 52, 530-533. [CrossRef] [PubMed]

11. Pecchio, M.; Suárez, J.A.; Hesse, S.; Hersh, A.M.; Gundacker, N.D. Descriptive epidemiology of snakebites in the Veraguas province of Panama, 2007-2008. Trans. R. Soc. Trop. Med. Hyg. 2018, 112, 463-466. [CrossRef]

12. Carrasco, P.A.; Venegas, P.J.; Chaparro, J.C.; Scrocchi, G.J. Nomenclatural instability in the venomous snakes of the bothrops complex: Implications in toxinology and public health. Toxicon 2016, 119, 122-128. [CrossRef]

13. Monteiro, W.M.; Contreras-Bernal, J.C.; Bisneto, P.F.; Sachett, J.; Mendonça da Silva, I.; Lacerda, M.; Guimarães da Costa, A.; Val, F.; Brasileiro, L.; Sartim, M.A.; et al. Bothrops atrox, the most important snake involved in human envenomings in the Amazon: How venomics contributes to the knowledge of snake biology and clinical toxinology. Toxicon X 2020, 6, 100037. [CrossRef] [PubMed]

14. Sasa, M.; Segura Cano, S.E. New insights into snakebite epidemiology in Costa Rica: A retrospective evaluation of medical records. Toxicon X 2020, 7, 100055. [CrossRef] [PubMed]

15. Ribeiro, L.A.; Jorge, M.T. Bites by snakes in the genus Bothrops: A series of 3139 cases. Rev. Soc. Bras. Med. Trop. 1997, 30, 475-480. [CrossRef]

16. Otero-Patiño, R. Epidemiological, clinical and therapeutic aspects of bothrops asper bites. Toxicon 2009, 54, 998-1011. [CrossRef]

17. Hamdan, B.; Guedes, T.B.; Carrasco, P.A.; Melville, J. A Complex biogeographic history of diversification in neotropical lancehead pitvipers (serpentes, viperidae). Zool. Scr. 2020, 49, 145-158. [CrossRef]

18. Fenwick, A.M.; Gutberlet, R.L.; Evans, J.A.; Parkinson, C.L. Morphological and molecular evidence for phylogeny and classification of South American pitvipers, Genera bothrops, bothriopsis, and bothrocophias (Serpentes: Viperidae). Zool. J. Linn. Soc. 2009, 156, 617-640. [CrossRef]

19. Carrasco, P.A.; Mattoni, C.; Leynaud, G.; Scrocchi, G. Morphology, phylogeny and taxonomy of South American bothropoid pitvipers (Serpentes, Viperidae). Zool. Scr. 2012, 41, 109-124. [CrossRef]

20. Tasoulis, T.; Isbister, G.K. A review and database of snake venom proteomes. Toxins 2017, 9, 290. [CrossRef] [PubMed]

21. Lasne, D.; Jude, B.; Susen, S. From normal to pathological hemostasis. Can. J. Anaesth. 2006, 53, S2-S11. [CrossRef]

22. Arnout, J.; Hoylaerts, M.F.; Lijnen, H.R. Haemostasis. Handb. Exp. Pharmacol. 2006, 1-41. [CrossRef]

23. Hoffman, M.; Monroe, D.M. A cell-based model of hemostasis. Thromb. Haemost. 2001, 85, 958-965.

24. Simurda, T.; Brunclikova, M.; Asselta, R.; Caccia, S.; Zolkova, J.; Kolkova, Z.; Loderer, D.; Skornova, I.; Hudecek, J.; Lasabova, Z.; et al. Genetic variants in the FGB and FGG genes mapping in the Beta and Gamma nodules of the fibrinogen molecule in congenital quantitative fibrinogen disorders associated with a thrombotic phenotype. Int. J. Mol. Sci. 2020, 21, 4616. [CrossRef]

25. Pryzdial, E.L.G.; Lee, F.M.H.; Lin, B.H.; Carter, R.L.R.; Tegegn, T.Z.; Belletrutti, M.J. Blood Coagulation Dissected. Transfus. Apher Sci. 2018, 57, 449-457. [CrossRef]

26. Simurda, T.; Vilar, R.; Zolkova, J.; Ceznerova, E.; Kolkova, Z.; Loderer, D.; Neerman-Arbez, M.; Casini, A.; Brunclikova, M.; Skornova, I.; et al. A novel nonsense mutation in FGB (c.1421G>A; p.Trp474Ter) in the Beta chain of fibrinogen causing hypofibrinogenemia with bleeding phenotype. Biomedicines 2020, 8, 605. [CrossRef] [PubMed]

27. Gutiérrez, J.M.; Rucavado, A.; Chaves, F.; Díaz, C.; Escalante, T. Experimental pathology of local tissue damage induced by bothrops asper snake venom. Toxicon 2009, 54, 958-975. [CrossRef] [PubMed]

28. Silva de Oliveira, S.; Campos Alves, E.; Dos Santos Santos, A.; Freitas Nascimento, E.; Tavares Pereira, J.P.; Mendonça da Silva, I.; Sachett, J.; Dos Santos Ibiapina, H.N.; Santos Sarraf, L.K.; Contreras Bernal, J.C.; et al. Bothrops snakebites in the Amazon: Recovery from hemostatic disorders after brazilian antivenom therapy. Clin. Toxicol. 2020, 58, 266-274. [CrossRef]

29. Oliveira, S.S.; Alves, E.C.; Santos, A.S.; Pereira, J.P.T.; Sarraff, L.K.S.; Nascimento, E.F.; de-Brito-Sousa, J.D.; Sampaio, V.S.; Lacerda, M.V.G.; Sachett, J.A.G.; et al. Factors associated with systemic bleeding in bothrops envenomation in a Tertiary Hospital in the Brazilian Amazon. Toxins 2019, 11, 22. [CrossRef] 
30. Nicoleti, A.F.; Medeiros, C.R.; Duarte, M.R.; França, F.O. Comparison of bothropoides Jararaca bites with and without envenoming treated at the Vital Brazil Hospital of the Butantan Institute, State of São Paulo, Brazil. Rev. Soc. Bras. Med. Trop. 2010, 43, 657-661. [CrossRef]

31. Thomas, L.; Tyburn, B.; Ketterle, J.; Rieux, D.; Garnier, D.; Smadja, D. Troubles de la coagulation et thromboses induits par la morsure de serpent (bothrops lanceolatus) chez l'homme en Martinique. Réanimation Urgences 1994, 3, 25-30. [CrossRef]

32. Otero-Patiño, R.; Segura, A.; Herrera, M.; Angulo, Y.; León, G.; Gutiérrez, J.M.; Barona, J.; Estrada, S.; Pereañez, A.; Quintana, J.C.; et al. Comparative study of the efficacy and safety of two polyvalent, caprylic acid fractionated [IgG and F(Ab')2] antivenoms, in bothrops asper bites in Colombia. Toxicon 2012, 59, 344-355. [CrossRef] [PubMed]

33. Bucaretchi, F.; Herrera, S.R.; Hyslop, S.; Baracat, E.C.; Vieira, R.J. Snakebites by bothrops Spp in children in Campinas, São Paulo, Brazil. Rev. Inst. Med. Trop. Sao Paulo 2001, 43, 329-333. [CrossRef]

34. Pardal, P.P.; Souza, S.M.; Monteiro, M.R.; Fan, H.W.; Cardoso, J.L.; França, F.O.; Tomy, S.C.; Sano-Martins, I.S.; de Sousa-e-Silva, M.C.C.; Colombini, M.; et al. Clinical trial of two antivenoms for the treatment of bothrops and lachesis bites in the North Eastern Amazon region of Brazil. Trans. R. Soc. Trop. Med. Hyg. 2004, 98, 28-42. [CrossRef]

35. Cunha, F.C.; Heerdt, M.; Torrez, P.P.; França, F.O.; Molin, G.Z.; Battisti, R.; Zannin, M. First report of hepatic hematoma after presumed bothrops envenomation. Rev. Soc. Bras. Med. Trop. 2015, 48, 633-635. [CrossRef]

36. Pinto, L.J.; Lee Fernández, L.; Gutiérrez, J.M.; Simón, D.S.; Ceballos, Z.; Aguilar, L.F.; Sierra, M. Case report: Hemothorax in envenomation by the viperid snake bothrops asper. Am. J. Trop. Med. Hyg. 2019, 100, 714-716. [CrossRef]

37. Benvenuti, L.A.; França, F.O.S.; Barbaro, K.C.; Nunes, J.R.; Cardoso, J.L.C. Pulmonary haemorrhage causing rapid death after bothrops Jararacussu snakebite: A case report. Toxicon 2003, 42, 331-334. [CrossRef]

38. Pérez-Gómez, A.S.; Monteiro, W.M.; João, G.A.P.; Sousa, J.D.B.; Safe, I.P.; Damian, M.M.; Sachett, J.A.G.; Silva, I.M.D. Hemorrhagic Stroke Following Viper Bites and Delayed Antivenom Administration: Three Case Reports from the Western Brazilian Amazon. Rev. Soc. Bras. Med. Trop. 2019, 52, e20190115. [CrossRef]

39. Delgado, A.B.T.; Gondim, C.C.V.L.; Reichert, L.P.; da Silva, P.H.V.; Souza, R.M.D.C.E.; Fernandes, T.M.P.; Calvo, B.F. Hemorrhagic stroke secondary to bothrops Spp. venom: A case report. Toxicon 2017, 132, 6-8. [CrossRef]

40. Mosquera, A.; Idrovo, L.A.; Tafur, A.; Del Brutto, O.H. stroke following bothrops Spp. snakebite. Neurology 2003, 60, 1577-1580. [CrossRef]

41. Sachett, J.A.G.; Mota da Silva, A.; Dantas, A.W.C.B.; Dantas, T.R.; Colombini, M.; Moura da Silva, A.M.; Monteiro, W.M.; Bernarde, P.S. Cerebrovascular accidents related to snakebites in the Amazon-two case reports. Wilderness Environ. Med. 2020, 31, 337-343. [CrossRef]

42. Jorge, M.T.; Ribeiro, L.A.; O'Connell, J.L. Prognostic factors for amputation in the Case of envenoming by snakes of the bothrops genus (Viperidae). Ann. Trop. Med. Parasitol. 1999, 93, 401-408. [CrossRef] [PubMed]

43. SOliveira, S.; CAlves, E.; SSantos, A.; FNascimento, E.; TPereira, J.P.; MSilva, I.; AG Sachett, J.; SSarraff, L.K.; Freitas-de-Sousa, L.A.; Colombini, M.; et al. Bleeding disorders in bothrops atrox envenomations in the Brazilian Amazon: Participation of hemostatic factors and the Impact of tissue factor. Toxins 2020, 12, 554. [CrossRef] [PubMed]

44. Santoro, M.L.; Sano-Martins, I.S.; Fan, H.W.; Cardoso, J.L.C.; Theakston, R.D.G.; Warrell, D.A. Butantan Institute Antivenom Study Group. Haematological evaluation of patients bitten by the Jararaca, Bothrops Jararaca, in Brazil. Toxicon 2008, 51, 1440-1448. [CrossRef]

45. Kamiguti, A.S.; Cardoso, J.L.; Theakston, R.D.; Sano-Martins, I.S.; Hutton, R.A.; Rugman, F.P.; Warrell, D.A.; Hay, C.R. Coagulopathy and haemorrhage in human victims of Bothrops Jararaca envenoming in Brazil. Toxicon 1991, 29, 961-972. [CrossRef]

46. Sano-Martins, I.S.; Santoro, M.L.; Castro, S.C.; Fan, H.W.; Cardoso, J.L.; Theakston, R.D. Platelet aggregation in patients bitten by the brazilian snake Bothrops Jararaca. Thromb. Res. 1997, 87, 183-195. [CrossRef]

47. Resiere, D.; Houcke, S.; Pujo, J.M.; Mayence, C.; Mathien, C.; NkontCho, F.; Blaise, N.; Demar, M.P.; Hommel, D.; Kallel, H. Clinical features and management of snakebite envenoming in French Guiana. Toxins 2020, 12, 662. [CrossRef]

48. Dempfle, C.E.; Kohl, R.; Harenberg, J.; Kirschstein, W.; Schlauch, D.; Heene, D.L. Coagulopathy after snake bite by Bothrops Neuwiedi: Case report and results of in vitro experiments. Blut 1990, 61, 369-374. [CrossRef]

49. Heckmann, X.; Lambert, V.; Mion, G.; Ehrhardt, A.; Marty, C.; Perotti, F.; Carod, J.-F.; Jolivet, A.; Boels, D.; Lehida Andi, I.; et al. Failure of a Mexican antivenom on recovery from snakebite-related coagulopathy in French Guiana. Clin. Toxicol. 2021, 59, 193-199. [CrossRef]

50. Sachetto, A.T.A.; Jensen, J.R.; Santoro, M.L. Liver gene regulation of hemostasis-related factors is altered by experimental snake envenomation in mice. PLoS Negl. Trop. Dis. 2020, 14, e0008379. [CrossRef] [PubMed]

51. Sano-Martins, I.S.; Fan, H.W.; Castro, S.C.; Tomy, S.C.; Franca, F.O.; Jorge, M.T.; Kamiguti, A.S.; Warrell, D.A.; Theakston, R.D. Reliability of the simple 20 minute whole blood clotting test (WBCT20) as an indicator of low plasma fibrinogen concentration in patients envenomed by Bothrops snakes. Butantan institute antivenom study group. Toxicon 1994, 32, 1045-1050. [CrossRef]

52. Kamiguti, A.S.; Rugman, F.P.; Theakston, R.D.; Franca, F.O.; Ishii, H.; Hay, C.R. The role of venom haemorrhagin in Spontaneous bleeding in Bothrops Jararaca envenoming. Butantan institute antivenom study group. Thromb. Haemost. 1992, 67, 484-488. [PubMed]

53. Bucaretchi, F.; Pimenta, M.M.B.; Borrasca-Fernandes, C.F.; Prado, C.C.; Capitani, E.M.D.; Hyslop, S. Thrombotic microangiopathy following Bothrops Jararaca snakebite: Case report. Clin. Toxicol. 2019, 57, 294-299. [CrossRef] [PubMed] 
54. Malaque, C.M.S.; Duayer, I.F.; Santoro, M.L. Acute kidney injury induced by thrombotic microangiopathy in two cases of bothrops envenomation. Clin. Toxicol. 2019, 57, 213-216. [CrossRef] [PubMed]

55. Fuchs, J.; Faber, K.; Tuchscherer, D.T.; Tsakiris, D.A.; Weiler, S.; Hofer, K.E. Bite by a Juvenile Bothrops venezuelensis (Venezuelan Lancehead) resulting in severe envenomation: A case report. Toxicon 2020, 180, 39-42. [CrossRef]

56. Mota, S.M.B.; Albuquerque, P.L.M.M.; Silva Júnior, G.B.D.; Daher, E.F. Thrombotic microangiopathy due to Bothrops Erythromelas: A case report in Northeast Brazil. Rev. Inst. Med. Trop. Sao Paulo 2020, 62, e53. [CrossRef]

57. Resiere, D.; Mégarbane, B.; Valentino, R.; Mehdaoui, H.; Thomas, L. Bothrops lanceolatus bites: Guidelines for severity assessment and emergent management. Toxins 2010, 2, 163-173. [CrossRef] [PubMed]

58. Thomas, L.; Tyburn, B.; Bucher, B.; Pecout, F.; Ketterle, J.; Rieux, D.; Smadja, D.; Garnier, D.; Plumelle, Y. Prevention of thromboses in human patients with Bothrops Lanceolatus Envenoming in Martinique: Failure of anticoagulants and efficacy of a monospecific antivenom. Research Group on snake bites in Martinique. Am. J. Trop. Med. Hyg. 1995, 52, 419-426. [CrossRef] [PubMed]

59. Thomas, L.; Tyburn, B.; Ketterlé, J.; Biao, T.; Mehdaoui, H.; Moravie, V.; Rouvel, C.; Plumelle, Y.; Bucher, B.; Canonge, D.; et al. Prognostic significance of clinical grading of patients envenomed by Bothrops Lanceolatus in Martinique. Members of the research group on snake bite in Martinique. Trans. R. Soc. Trop. Med. Hyg. 1998, 92, 542-545. [CrossRef]

60. Malbranque, S.; Piercecchi-Marti, M.D.; Thomas, L.; Barbey, C.; Courcier, D.; Bucher, B.; Ridarch, A.; Smadja, D.; Warrell, D.A. Fatal diffuse thrombotic microangiopathy after a bite by the "Fer-de-Lance" Pit Viper (Bothrops Lanceolatus) of Martinique. Am. J. Trop. Med. Hyg. 2008, 78, 856-861. [CrossRef]

61. Numeric, P.; Moravie, V.; Didier, M.; Chatot-Henry, D.; Cirille, S.; Bucher, B.; Thomas, L. Multiple cerebral infarctions following a snakebite by Bothrops Caribbaeus. Am. J. Trop. Med. Hyg. 2002, 67, 287-288. [CrossRef]

62. Gutiérrez, J.M.; Romero, M.; Núñez, J.; Chaves, F.; Borkow, G.; Ovadia, M. Skeletal Muscle necrosis and regeneration after injection of $\mathrm{BaH} 1$, a hemorrhagic metalloproteinase isolated from the venom of the snake Bothrops Asper (Terciopelo). Exp. Mol. Pathol. 1995, 62, 28-41. [CrossRef]

63. Petretski, J.H.; Kanashiro, M.M.; Rodrigues, F.R.; Alves, E.W.; Machado, O.L.; Kipnis, T.L. Edema Induction by the disintegrinlike/cysteine-rich domains from a bothrops atrox hemorrhagin. Biochem. Biophys. Res. Commun. 2000, 276, 29-34. [CrossRef]

64. Gutiérrez, J.M.; Escalante, T.; Rucavado, A. experimental pathophysiology of systemic alterations induced by bothrops asper snake venom. Toxicon 2009, 54, 976-987. [CrossRef]

65. Chacón, F.; Oviedo, A.; Escalante, T.; Solano, G.; Rucavado, A.; Gutiérrez, J.M. The lethality test used for estimating the potency of antivenoms against bothrops asper snake venom: Pathophysiological mechanisms, prophylactic analgesia, and a surrogate in vitro assay. Toxicon 2015, 93, 41-50. [CrossRef] [PubMed]

66. Rodrigues Sgrignolli, L.; Florido Mendes, G.E.; Carlos, C.P.; Burdmann, E.A. Acute kidney injury caused by bothrops snake venom. Nephron. Clin. Pract. 2011, 119, c131-c136, discussion c137. [CrossRef] [PubMed]

67. Albuquerque, P.L.M.M.; Paiva, J.H.H.G.L.; Martins, A.M.C.; Meneses, G.C.; da Silva, G.B.; Buckley, N.; Daher, E.D.F. Clinical assessment and pathophysiology of bothrops venom-related acute kidney injury: A scoping review. J. Venom. Anim. Toxins Incl. Trop. Dis. 2020, 26, e20190076. [CrossRef]

68. Alves, E.C.; Sachett, J.A.G.; Sampaio, V.S.; Sousa, J.D.B.; Oliveira, S.S.; Nascimento, E.F.D.; Santos, A.D.S.; da Silva, I.M.; da Silva, A.M.M.; Wen, F.H.; et al. Predicting acute renal failure in bothrops snakebite patients in a tertiary reference center, Western Brazilian Amazon. PLoS ONE 2018, 13, e0202361. [CrossRef] [PubMed]

69. Teixeira, C.; Fernandes, C.M.; Leiguez, E.; Chudzinski-Tavassi, A.M. Inflammation induced by platelet-activating viperid snake venoms: Perspectives on Thromboinflammation. Front. Immunol. 2019, 10, 2082. [CrossRef] [PubMed]

70. Slagboom, J.; Kool, J.; Harrison, R.A.; Casewell, N.R. Haemotoxic snake venoms: Their functional activity, impact on snakebite victims and pharmaceutical promise. Br. J. Haematol. 2017, 177, 947-959. [CrossRef]

71. Otero, R.; León, G.; Gutiérrez, J.M.; Rojas, G.; Toro, M.F.; Barona, J.; Rodríguez, V.; Díaz, A.; Núñez, V.; Quintana, J.C.; et al. Efficacy and safety of two whole IgG polyvalent antivenoms, refined by caprylic acid fractionation with or without Beta-propiolactone, in the treatment of bothrops asper bites in Colombia. Trans. R. Soc. Trop. Med. Hyg. 2006, 100, 1173-1182. [CrossRef] [PubMed]

72. Jorge, M.T.; Cardoso, J.L.; Castro, S.C.; Ribeiro, L.; França, F.O.; de Almeida, M.E.; Kamiguti, A.S.; Santo-Martins, I.S.; Santoro, M.L.; Mancau, J.E. A randomized "blinded" comparison of two doses of antivenom in the treatment of bothrops envenoming in São Paulo, Brazil. Trans. R. Soc. Trop. Med. Hyg. 1995, 89, 111-114. [CrossRef]

73. Smalligan, R.; Cole, J.; Brito, N.; Laing, G.D.; Mertz, B.L.; Manock, S.; Maudlin, J.; Quist, B.; Holland, G.; Nelson, S.; et al. Crotaline snake bite in the ecuadorian amazon: Randomised double blind comparative trial of three South American polyspecific antivenoms. BMJ 2004, 329, 1129. [CrossRef]

74. Otero, R.; Gutiérrez, J.M.; Núñez, V.; Robles, A.; Estrada, R.; Segura, E.; Toro, M.F.; García, M.E.; Díaz, A.; Ramírez, E.C.; et al. A randomized double-blind clinical trial of two antivenoms in patients bitten by bothrops atrox in Colombia. The regional group on antivenom therapy research (REGATHER). Trans. R. Soc. Trop. Med. Hyg. 1996, 90, 696-700. [CrossRef]

75. Thomas, L.; Tyburn, B.; Lang, J.; Ketterle, J. Early Infusion of a purified monospecific F(Ab')2 antivenom serum for bothrops lanceolatus bites in Martinique. Lancet 1996, 347, 406. [CrossRef]

76. Thomas, L.; Chausson, N.; Uzan, J.; Kaidomar, S.; Vignes, R.; Plumelle, Y.; Bucher, B.; Smadja, D. Thrombotic stroke following snake bites by the "fer-de-lance"bothrops lanceolatus in Martinique despite antivenom treatment: A report of three recent cases. Toxicon 2006, 48, 23-28. [CrossRef] [PubMed] 
77. Fox, J.W.; Serrano, S.M.T. Structural considerations of the snake venom metalloproteinases, key members of the M12 reprolysin family of metalloproteinases. Toxicon 2005, 45, 969-985. [CrossRef]

78. Markland, F.S.; Swenson, S. Snake venom metalloproteinases. Toxicon 2013, 62, 3-18. [CrossRef]

79. Sanchez, E.F.; Flores-Ortiz, R.J.; Alvarenga, V.G.; Eble, J.A. Direct fibrinolytic snake venom metalloproteinases affecting hemostasis: Structural, biochemical features and therapeutic potential. Toxins 2017, 9, 392. [CrossRef]

80. Camacho, E.; Escalante, T.; Remans, K.; Gutiérrez, J.M.; Rucavado, A. site mutation of residues in a loop surrounding the active site of a pi snake venom metalloproteinase abrogates its hemorrhagic activity. Biochem. Biophys. Res. Commun. 2019, 512, 859-863. [CrossRef]

81. Watanabe, L.; Shannon, J.D.; Valente, R.H.; Rucavado, A.; Alape-Girón, A.; Kamiguti, A.S.; Theakston, R.D.G.; Fox, J.W.; Gutiérrez, J.M.; Arni, R.K. Amino acid sequence and crystal structure of BaP1, a metalloproteinase from bothrops asper snake venom that exerts multiple tissue-damaging activities. Protein Sci. 2003, 12, 2273-2281. [CrossRef]

82. Akao, P.K.; Tonoli, C.C.C.; Navarro, M.S.; Cintra, A.C.O.; Neto, J.R.; Arni, R.K.; Murakami, M.T. Structural studies of BmooMPalpha-I, a non-hemorrhagic metalloproteinase from bothrops moojeni venom. Toxicon 2010, 55, 361-368. [CrossRef]

83. Calvete, J.J.; Marcinkiewicz, C.; Monleón, D.; Esteve, V.; Celda, B.; Juárez, P.; Sanz, L. Snake venom disintegrins: Evolution of structure and function. Toxicon 2005, 45, 1063-1074. [CrossRef] [PubMed]

84. Olaoba, O.T.; Karina Dos Santos, P.; Selistre-de-Araujo, H.S.; Ferreira de Souza, D.H. Snake venom metalloproteinases (SVMPs): A structure-function update. Toxicon X 2020, 7, 100052. [CrossRef] [PubMed]

85. Laing, G.D.; Moura-da-Silva, A.M. Jararhagin and its multiple effects on hemostasis. Toxicon 2005, 45, 987-996. [CrossRef]

86. García, L.T.; Parreiras e Silva, L.T.; Ramos, O.H.P.; Carmona, A.K.; Bersanetti, P.A.; Selistre-de-Araujo, H.S. The effect of posttranslational modifications on the hemorrhagic activity of snake venom metalloproteinases. Comp. Biochem. Physiol. Part C Toxicol. Pharmacol. 2004, 138, 23-32. [CrossRef] [PubMed]

87. Kini, R.M. Serine proteases affecting blood coagulation and fibrinolysis from snake venoms. Pathophysiol. Haemost. Thromb. 2005, 34, 200-204. [CrossRef] [PubMed]

88. Sajevic, T.; Leonardi, A.; Križaj, I. Haemostatically active proteins in snake venoms. Toxicon 2011, 57, 627-645. [CrossRef] [PubMed]

89. Montecucco, C.; Gutiérrez, J.M.; Lomonte, B. Cellular pathology induced by snake venom phospholipase A2 myotoxins and neurotoxins: Common aspects of their mechanisms of action. Cell. Mol. Life Sci. 2008, 65, 2897-2912. [CrossRef]

90. Six, D.A.; Dennis, E.A. The expanding superfamily of phospholipase A(2) enzymes: Classification and characterization. Biochim. Biophys. Acta 2000, 1488, 1-19. [CrossRef]

91. De Queiroz, M.R.; de Sousa, B.B.; da Cunha Pereira, D.F.; Mamede, C.C.N.; Matias, M.S.; de Morais, N.C.G.; de Oliveira Costa, J.; de Oliveira, F. The role of platelets in hemostasis and the effects of snake venom toxins on platelet function. Toxicon 2017, 133, 33-47. [CrossRef]

92. Paloschi, M.V.; Pontes, A.S.; Soares, A.M.; Zuliani, J.P. An update on potential molecular mechanisms underlying the actions of snake venom l-amino acid oxidases (LAAOs). Curr. Med. Chem. 2018, 25, 2520-2530. [CrossRef] [PubMed]

93. Lazarovici, P.; Marcinkiewicz, C.; Lelkes, P.I. from snake venom's disintegrins and C-type lectins to anti-platelet drugs. Toxins 2019, 11, 303. [CrossRef] [PubMed]

94. Cesar, P.H.S.; Braga, M.A.; Trento, M.V.C.; Menaldo, D.L.; Marcussi, S. Snake venom disintegrins: An overview of their interaction with integrins. Curr. Drug Targets 2019, 20, 465-477. [CrossRef] [PubMed]

95. Eble, J.A. Structurally robust and functionally highly versatile-C-type lectin (-Related) proteins in snake venoms. Toxins 2019, 11, 136. [CrossRef]

96. Clemetson, K.J.; Lu, Q.; Clemetson, J.M. Snake C-type Lectin-like proteins and platelet receptors. Pathophysiol. Haemost. Thromb. 2005, 34, 150-155. [CrossRef]

97. Gutiérrez, J.M.; Sanz, L.; Escolano, J.; Fernández, J.; Lomonte, B.; Angulo, Y.; Rucavado, A.; Warrell, D.A.; Calvete, J.J. Snake venomics of the lesser antillean pit vipers bothrops caribbaeus and bothrops lanceolatus: Correlation with toxicological activities and immunoreactivity of a heterologous antivenom. J. Proteome Res. 2008, 7, 4396-4408. [CrossRef]

98. Terra, R.M.S.; Pinto, A.F.M.; Guimarães, J.A.; Fox, J.W. Proteomic Profiling of Snake Venom Metalloproteinases (SVMPs): Insights into venom induced pathology. Toxicon 2009, 54, 836-844. [CrossRef]

99. Freitas-de-Sousa, L.A.; Nachtigall, P.G.; Portes-Junior, J.A.; Holding, M.L.; Nystrom, G.S.; Ellsworth, S.A.; Guimarães, N.C.; Tioyama, E.; Ortiz, F.; Silva, B.R.; et al. Size matters: An evaluation of the Molecular Basis of Ontogenetic Modifications in the Composition of Bothrops Jararacussu snake venom. Toxins 2020, 12, 791. [CrossRef]

100. Núñez, V.; Cid, P.; Sanz, L.; De La Torre, P.; Angulo, Y.; Lomonte, B.; Gutiérrez, J.M.; Calvete, J.J. snake venomics and antivenomics of Bothrops Atrox Venoms from Colombia and the Amazon regions of Brazil, Perú and Ecuador suggest the occurrence of geographic variation of venom phenotype by a trend towards paedomorphism. J. Proteom. 2009, 73, 57-78. [CrossRef]

101. Calvete, J.J.; Sanz, L.; Pérez, A.; Borges, A.; Vargas, A.M.; Lomonte, B.; Angulo, Y.; Gutiérrez, J.M.; Chalkidis, H.M.; Mourão, R.H.V.; et al. Snake population venomics and antivenomics of Bothrops Atrox: Paedomorphism along its transamazonian dispersal and implications of geographic venom variability on snakebite management. J. Proteom. 2011, 74, 510-527. [CrossRef]

102. Kohlhoff, M.; Borges, M.H.; Yarleque, A.; Cabezas, C.; Richardson, M.; Sanchez, E.F. Exploring the proteomes of the venoms of the Peruvian Pit Vipers Bothrops atrox, B. barnetti and B. pictus. J. Proteom. 2012, 75, 2181-2195. [CrossRef] [PubMed] 
103. Hatakeyama, D.M.; Tasima, L.J.; Bravo-Tobar, C.A.; Serino-Silva, C.; Tashima, A.K.; Rodrigues, C.F.B.; Aguiar, W.D.S.; Galizio, N.D.C.; de Lima, E.O.V.; Kavazoi, V.K.; et al. Venom complexity of Bothrops Atrox (Common lancehead) siblings. J. Venom. Anim. Toxins Incl. Trop. Dis. 2020, 26, e20200018. [CrossRef] [PubMed]

104. Alape-Girón, A.; Flores-Díaz, M.; Sanz, L.; Madrigal, M.; Escolano, J.; Sasa, M.; Calvete, J.J. Studies on the venom proteome of Bothrops Asper: Perspectives and applications. Toxicon 2009, 54, 938-948. [CrossRef] [PubMed]

105. Mora-Obando, D.; Salazar-Valenzuela, D.; Pla, D.; Lomonte, B.; Guerrero-Vargas, J.A.; Ayerbe, S.; Gibbs, H.L.; Calvete, J.J. Venom variation in Bothrops Asper lineages from North-Western South America. J. Proteom. 2020, 229, 103945. [CrossRef]

106. Gonçalves-Machado, L.; Pla, D.; Sanz, L.; Jorge, R.J.B.; Leitão-De-Araújo, M.; Alves, M.L.M.; Alvares, D.J.; De Miranda, J.; Nowatzki, J.; de Morais-Zani, K.; et al. Combined venomics, venom gland transcriptomics, bioactivities, and antivenomics of two bothrops jararaca populations from geographic isolated regions within the Brazilian Atlantic rainforest. J. Proteom. 2016, 135, 73-89. [CrossRef]

107. Da Costa Galizio, N.; Serino-Silva, C.; Stuginski, D.R.; Abreu PA, E.; Sant'Anna, S.S.; Grego, K.F.; de Morais-Zani, K. Compositional and functional investigation of individual and pooled venoms from long-term captive and recently wild-caught Bothrops Jararaca snakes. J. Proteom. 2018, 186, 56-70. [CrossRef]

108. Augusto-de-Oliveira, C.; Stuginski, D.R.; Kitano, E.S.; Andrade-Silva, D.; Liberato, T.; Fukushima, I.; Serrano, S.M.T.; Zelanis, A. Dynamic rearrangement in snake venom gland proteome: Insights into Bothrops Jararaca intraspecific venom variation. $J$. Proteome Res. 2016, 15, 3752-3762. [CrossRef]

109. Jorge, R.J.; Monteiro, H.S.; Gonçalves-Machado, L.; Guarnieri, M.C.; Ximenes, R.M.; Borges-Nojosa, D.M.; Luna, K.P.; Zingali, R.B.; Corrêa-Netto, C.; Gutiérrez, J.M.; et al. Venomics and antivenomics of Bothrops Erythromelas from five geographic populations within the caatinga ecoregion of Northeastern Brazil. J. Proteom. 2015, 114, 93-114. [CrossRef]

110. Rodrigues, C.F.B.; Zdenek, C.N.; Bourke, L.A.; Seneci, L.; Chowdhury, A.; Freitas-de-Sousa, L.A.; de Alcantara Menezes, F.; Moura-da-Silva, A.M.; Tanaka-Azevedo, A.M.; Fry, B.G. Clinical implications of ontogenetic differences in the coagulotoxic activity of Bothrops Jararacussu venoms. Toxicol. Lett. 2021, 348, 59-72. [CrossRef]

111. Girón, M.E.; Padrón, V.; Ramos, M.I.; Sánchez, E.E.; Guerrero, B.; García, A.; Uzcátegui, N.L.; Navarrete, L.F.; Rodríguez-Acosta, A. intraspecies geographical variability in the South American tigra mariposa (Bothrops Venezuelensis Sandner 1952) snake venom activities. Toxicon 2018, 144, 23-33. [CrossRef]

112. Saldarriaga, M.M.; Otero, R.; Núñez, V.; Toro, M.F.; Díaz, A.; Gutiérrez, J.M. Ontogenetic variability of Bothrops Atrox and Bothrops Asper snake venoms from Colombia. Toxicon 2003, 42, 405-411. [CrossRef]

113. Alape-Girón, A.; Sanz, L.; Escolano, J.; Flores-Díaz, M.; Madrigal, M.; Sasa, M.; Calvete, J.J. Snake venomics of the lancehead pitviper Bothrops Asper: Geographic, individual, and ontogenetic variations. J. Proteome Res. 2008, 7, 3556-3571. [CrossRef] [PubMed]

114. Bernal, J.C.C.; Bisneto, P.F.; Pereira, J.P.T.; Ibiapina, H.N.D.S.; Sarraff, L.K.S.; Monteiro-Júnior, C.; da Silva Pereira, H.; Santos, B.; de Moura, V.M.; de Oliveira, S.S.; et al. "Bad things come in small packages": Predicting venom-induced coagulopathy in bothrops atrox bites using snake ontogenetic parameters. Clin. Toxicol 2020, 58, 388-396. [CrossRef] [PubMed]

115. Amazonas, D.R.; Freitas-de-Sousa, L.A.; Orefice, D.P.; Sousa, L.F.; Martinez, M.G.; Mourão, R.H.V.; Chalkidis, H.M.; Camargo, P.B.; Moura-da-Silva, A.M. Evidence for snake venom plasticity in a long-term study with individual captive Bothrops Atrox. Toxins 2019, 11, 294. [CrossRef]

116. Patiño, R.S.P.; Salazar-Valenzuela, D.; Medina-Villamizar, E.; Mendes, B.; Proaño-Bolaños, C.; da Silva, S.L.; Almeida, J.R. Bothrops Atrox from Ecuadorian Amazon: Initial analyses of venoms from individuals. Toxicon 2021, 193, 63-72. [CrossRef]

117. Sousa, L.F.; Zdenek, C.N.; Dobson, J.S.; Op den Brouw, B.; Coimbra, F.; Gillett, A.; Del-Rei, T.H.M.; Chalkidis, H.M.; Sant'Anna, S.; Teixeira-da-Rocha, M.M.; et al. Coagulotoxicity of Bothrops (Lancehead Pit-Vipers) venoms from Brazil: Differential biochemistry and antivenom efficacy resulting from Prey-Driven venom variation. Toxins 2018, 10, 411. [CrossRef]

118. Lomonte, B.; Lundgren, J.; Johansson, B.; Bagge, U. The dynamics of local tissue damage induced by Bothrops Asper snake venom and myotoxin II on the mouse cremaster muscle: An intravital and electron microscopic study. Toxicon 1994, $32,41-55$. [CrossRef]

119. Farsky, S.H.; Gonçalves, L.R.; Cury, Y. Characterization of local tissue damage evoked by Bothrops Jararaca venom in the rat connective tissue microcirculation: An intravital microscopic study. Toxicon 1999, 37, 1079-1083. [CrossRef]

120. Moreira, L.; Gutiérrez, J.M.; Borkow, G.; Ovadia, M. Ultrastructural alterations in mouse capillary blood vessels after experimental injection of venom from the snake Bothrops Asper (Terciopelo). Exp. Mol. Pathol. 1992, 57, 124-133. [CrossRef]

121. Bogarín, G.; Romero, M.; Rojas, G.; Lutsch, C.; Casadamont, M.; Lang, J.; Otero, R.; Gutiérrez, J.M. Neutralization, by a monospecific Bothrops Lanceolatus antivenom, of toxic activities induced by homologous and heterologous Bothírops snake venoms. Toxicon 1999, 37, 551-557. [CrossRef]

122. Segura, A.; Castillo, M.C.; Núñez, V.; Yarlequé, A.; Gonçalves, L.R.C.; Villalta, M.; Bonilla, C.; Herrera, M.; Vargas, M.; Fernández, M.; et al. Preclinical assessment of the neutralizing capacity of antivenoms produced in six Latin American countries against medically-relevant Bothrops snake venoms. Toxicon 2010, 56, 980-989. [CrossRef] [PubMed]

123. Resiere, D.; Arias, A.S.; Villalta, M.; Rucavado, A.; Brouste, Y.; Cabié, A.; Névière, R.; Césaire, R.; Kallel, H.; Mégarbane, B.; et al. Preclinical evaluation of the neutralizing ability of a monospecific antivenom for the treatment of envenomings by Bothrops Lanceolatus in Martinique. Toxicon 2018, 148, 50-55. [CrossRef] [PubMed] 
124. Rucavado, A.; Lomonte, B.; Ovadia, M.; Gutiérrez, J.M. Local tissue damage induced by BaP1, a metalloproteinase isolated from Bothrops Asper (Terciopelo) snake venom. Exp. Mol. Pathol. 1995, 63, 186-199. [CrossRef]

125. Moreira, L.; Borkow, G.; Ovadia, M.; Gutiérrez, J.M. Pathological changes induced by BaH1, a hemorrhagic proteinase isolated from Bothrops Asper (Terciopelo) snake venom, on mouse capillary blood vessels. Toxicon 1994, 32, 976-987. [CrossRef]

126. Rucavado, A.; Escalante, T.; Franceschi, A.; Chaves, F.; León, G.; Cury, Y.; Ovadia, M.; Gutiérrez, J.M. Inhibition of local hemorrhage and dermonecrosis induced by Bothrops Asper snake venom: Effectiveness of early in situ administration of the peptidomimetic metalloproteinase inhibitor batimastat and the chelating agent CaNa2EDTA. Am. J. Trop. Med. Hyg. 2000, 63, 313-319. [CrossRef]

127. Lomonte, B.; Gutiérrez, J.M.; Borkow, G.; Ovadia, M.; Tarkowski, A.; Hanson, L.A. Activity of hemorrhagic metalloproteinase BaH-1 and Myotoxin II from Bothrops Asper snake venom on capillary endothelial cells in vitro. Toxicon 1994, 32, 505-510. [CrossRef]

128. Franceschi, A.; Rucavado, A.; Mora, N.; Gutiérrez, J.M. Purification and characterization of BaH4, a hemorrhagic metalloproteinase from the venom of the snake Bothrops Asper. Toxicon 2000, 38, 63-77. [CrossRef]

129. Schattner, M.; Fritzen, M.; Ventura Jde, S.; de Albuquerque Modesto, J.C.; Pozner, R.G.; Moura-da-Silva, A.M.; Chudzinski-Tavassi, A.M. The snake venom metalloproteases berythractivase and Jararhagin activate endothelial cells. Biol. Chem. 2005, 386, 369-374. [CrossRef]

130. Baldo, C.; Tanjoni, I.; León, I.R.; Batista, I.F.C.; Della-Casa, M.S.; Clissa, P.B.; Weinlich, R.; Lopes-Ferreira, M.; Lebrun, I.; Amarante-Mendes, G.P.; et al. BnP1, a novel P-I metalloproteinase from Bothrops Neuwiedi venom: Biological effects benchmarking relatively to Jararhagin, a P-III SVMP. Toxicon 2008, 51, 54-65. [CrossRef] [PubMed]

131. Escalante, T.; Shannon, J.; Moura-da-Silva, A.M.; Gutiérrez, J.M.; Fox, J.W. Novel insights into capillary vessel basement membrane damage by snake venom hemorrhagic metalloproteinases: A biochemical and immunohistochemical study. Arch. Biochem. Biophys. 2006, 455, 144-153. [CrossRef]

132. Escalante, T.; Ortiz, N.; Rucavado, A.; Sanchez, E.F.; Richardson, M.; Fox, J.W.; Gutiérrez, J.M. Role of collagens and perlecan in microvascular stability: Exploring the mechanism of capillary vessel damage by snake venom metalloproteinases. PLoS ONE 2011, 6, e28017. [CrossRef]

133. Anai, K.; Sugiki, M.; Yoshida, E.; Maruyama, M. Neutralization of a snake venom hemorrhagic metalloproteinase prevents coagulopathy after subcutaneous injection of Bothrops Jararaca venom in rats. Toxicon 2002, 40, 63-68. [CrossRef]

134. Herrera, C.; Macêdo, J.K.A.; Feoli, A.; Escalante, T.; Rucavado, A.; Gutiérrez, J.M.; Fox, J.W. Muscle tissue damage induced by the venom of Bothrops Asper: Identification of early and late pathological events through proteomic analysis. PLoS Negl. Trop. Dis. 2016, 10, e0004599. [CrossRef] [PubMed]

135. Herrera, C.; Escalante, T.; Voisin, M.-B.; Rucavado, A.; Morazán, D.; Macêdo, J.K.A.; Calvete, J.J.; Sanz, L.; Nourshargh, S.; Gutiérrez, J.M.; et al. Tissue localization and extracellular matrix degradation by PI, PII and PIII snake venom metalloproteinases: Clues on the mechanisms of venom-induced hemorrhage. PLoS Negl. Trop. Dis. 2015, 9, e0003731. [CrossRef]

136. Baldo, C.; Jamora, C.; Yamanouye, N.; Zorn, T.M.; Moura-da-Silva, A.M. Mechanisms of vascular damage by hemorrhagic snake venom metalloproteinases: Tissue distribution and in situ hydrolysis. PLoS Negl. Trop. Dis. 2010, 4, e727. [CrossRef] [PubMed]

137. Moura-da-Silva, A.M.; Ramos, O.H.P.; Baldo, C.; Niland, S.; Hansen, U.; Ventura, J.S.; Furlan, S.; Butera, D.; Della-Casa, M.S.; Tanjoni, I.; et al. Collagen binding is a key factor for the hemorrhagic activity of snake venom metalloproteinases. Biochimie 2008, 90, 484-492. [CrossRef]

138. Freitas-de-Sousa, L.A.; Colombini, M.; Lopes-Ferreira, M.; Serrano, S.M.T.; Moura-da-Silva, A.M. Insights into the mechanisms involved in strong hemorrhage and dermonecrosis induced by Atroxlysin-Ia, a PI-class snake venom metalloproteinase. Toxins 2017, 9, 239. [CrossRef]

139. Bustillo, S.; García-Denegri, M.E.; Gay, C.; Van de Velde, A.C.; Acosta, O.; Angulo, Y.; Lomonte, B.; Gutiérrez, J.M.; Leiva, L. Phospholipase A(2) enhances the endothelial cell detachment effect of a snake venom metalloproteinase in the absence of catalysis. Chem. Biol. Interact. 2015, 240, 30-36. [CrossRef]

140. Gutiérrez, J.M.; Núñez, J.; Escalante, T.; Rucavado, A. Blood flow is required for rapid endothelial cell damage induced by a snake venom hemorrhagic metalloproteinase. Microvasc. Res. 2006, 71, 55-63. [CrossRef]

141. Kawano, J.; Anai, K.; Sugiki, M.; Yoshida, E.; Maruyama, M. Vascular endothelial cell injury induced by Bothrops Jararaca Venom; non-significance of hemorrhagic metalloproteinase. Toxicon 2002, 40, 1553-1562. [CrossRef]

142. Jansson, J.H.; Boman, K.; Brännström, M.; Nilsson, T.K. High concentration of thrombomodulin in plasma is associated with hemorrhage: A prospective study in patients receiving long-term anticoagulant treatment. Circulation 1997, 96, $2938-2943$. [CrossRef] [PubMed]

143. Asega, A.F.; Menezes, M.C.; Trevisan-Silva, D.; Cajado-Carvalho, D.; Bertholim, L.; Oliveira, A.K.; Zelanis, A.; Serrano, S.M.T. Cleavage of proteoglycans, plasma proteins and the platelet-derived growth factor receptor in the hemorrhagic process induced by snake venom metalloproteinases. Sci. Rep. 2020, 10, 12912. [CrossRef]

144. Rucavado, A.; Soto, M.; Escalante, T.; Loría, G.D.; Arni, R.; Gutiérrez, J.M. Thrombocytopenia and platelet hypoaggregation induced by Bothrops Asper snake venom. toxins involved and their contribution to metalloproteinase-induced pulmonary hemorrhage. Thromb. Haemost. 2005, 94, 123-131. [CrossRef] [PubMed]

145. Rosa, J.G.; de Albuquerque, C.Z.; Mattaraia, V.G.M.; Santoro, M.L. Comparative study of platelet aggregation and secretion induced by Bothrops Jararaca snake venom and thrombin. Toxicon 2019, 159, 50-60. [CrossRef] 
146. Sartim, M.A.; Costa, T.R.; Laure, H.J.; Espíndola, M.S.; Frantz, F.G.; Sorgi, C.A.; Cintra, A.C.O.; Arantes, E.C.; Faccioli, L.H.; Rosa, J.C.; et al. Moojenactivase, a novel pro-coagulant PIIId metalloprotease isolated from bothrops moojeni snake venom, activates coagulation factors II and X and induces tissue factor up-regulation in Leukocytes. Arch. Toxicol. 2016, 90, 1261-1278. [CrossRef] [PubMed]

147. Senise, L.V.; Yamashita, K.M.; Santoro, M.L. Bothrops Jararaca envenomation: Pathogenesis of hemostatic disturbances and intravascular hemolysis. Exp. Biol. Med. 2015, 240, 1528-1536. [CrossRef] [PubMed]

148. Santos, B.F.; Serrano, S.M.; Kuliopulos, A.; Niewiarowski, S. Interaction of viper venom serine peptidases with thrombin receptors on human platelets. FEBS Lett. 2000, 477, 199-202. [CrossRef]

149. Nishida, S.; Fujimura, Y.; Miura, S.; Ozaki, Y.; Usami, Y.; Suzuki, M.; Titani, K.; Yoshida, E.; Sugimoto, M.; Yoshioka, A. Purification and characterization of bothrombin, a fibrinogen-clotting serine protease from the venom of Bothrops Jararaca. Biochemistry 1994, 33, 1843-1849. [CrossRef]

150. Rucavado, A.; Soto, M.; Kamiguti, A.S.; Theakston, R.D.; Fox, J.W.; Escalante, T.; Gutiérrez, J.M. Characterization of aspercetin, a platelet aggregating component from the venom of the snake Bothrops Asper which induces thrombocytopenia and potentiates metalloproteinase-induced hemorrhage. Thromb. Haemost. 2001, 85, 710-715.

151. Andrews, R.K.; Booth, W.J.; Gorman, J.J.; Castaldi, P.A.; Berndt, M.C. Purification of botrocetin from Bothrops Jararaca venom. analysis of the botrocetin-mediated interaction between von willebrand factor and the human platelet membrane glycoprotein Ib-IX complex. Biochemistry 1989, 28, 8317-8326. [CrossRef] [PubMed]

152. Fuly, A.L.; Soares, A.M.; Marcussi, S.; Giglio, J.R.; Guimarães, J.A. Signal transduction pathways involved in the platelet aggregation induced by a D-49 phospholipase A2 isolated from Bothrops Jararacussu snake venom. Biochimie 2004, 86, 731-739. [CrossRef]

153. Mounier, C.; Vargaftig, B.B.; Franken, P.A.; Verheij, H.M.; Bon, C.; Touqui, L. Platelet secretory phospholipase A2 fails to induce rabbit platelet activation and to release arachidonic acid in contrast with venom phospholipases A2. Biochim. Biophys. Acta 1994, 1214, 88-96. [CrossRef]

154. Stábeli, R.G.; Sant'Ana, C.D.; Ribeiro, P.H.; Costa, T.R.; Ticli, F.K.; Pires, M.G.; Nomizo, A.; Albuquerque, S.; Malta-Neto, N.R.; Marins, M.; et al. Cytotoxic L-amino acid oxidase from Bothrops Moojeni: Biochemical and functional characterization. Int. J. Biol. Macromol. 2007, 41, 132-140. [CrossRef]

155. Santoro, M.L.; Vaquero, T.S.; Paes Leme, A.F.; Serrano, S.M.T. NPP-BJ, a nucleotide pyrophosphatase/phosphodiesterase from Bothrops Jararaca snake venom, inhibits platelet aggregation. Toxicon 2009, 54, 499-512. [CrossRef] [PubMed]

156. Kamiguti, A.S.; Hay, C.R.; Theakston, R.D.; Zuzel, M. Insights into the mechanism of haemorrhage caused by snake venom metalloproteinases. Toxicon 1996, 34, 627-642. [CrossRef]

157. De Luca, M.; Ward, C.M.; Ohmori, K.; Andrews, R.K.; Berndt, M.C. Jararhagin and Jaracetin: Novel snake venom inhibitors of the integrin collagen receptor, Alpha 2 Beta 1. Biochem. Biophys. Res. Commun. 1995, 206, 570-576. [CrossRef]

158. Loría, G.D.; Rucavado, A.; Kamiguti, A.S.; Theakston, R.D.G.; Fox, J.W.; Alape, A.; Gutiérrez, J.M. Characterization of "basparin A," a prothrombin-activating metalloproteinase, from the venom of the snake Bothrops Asper that inhibits platelet aggregation and induces defibrination and thrombosis. Arch. Biochem. Biophys. 2003, 418, 13-24. [CrossRef]

159. Pinto, A.; Angulo, Y.; Jiménez, R.; Lomonte, B. Isolation of Bothrasperin, a disintegrin with potent platelet aggregation inhibitory activity, from the venom of the snake Bothrops Asper. Rev. Biol. Trop. 2003, 51, 253-259. [PubMed]

160. Serrano, S.M.; Reichl, A.P.; Mentele, R.; Auerswald, E.A.; Santoro, M.L.; Sampaio, C.A.; Camargo, A.C.; Assakura, M.T. A novel phospholipase A2, BJ-PLA2, from the venom of the snake Bothrops Jararaca: Purification, primary structure analysis, and its characterization as a platelet-aggregation-inhibiting factor. Arch. Biochem. Biophys. 1999, 367, 26-32. [CrossRef] [PubMed]

161. Roberto, P.G.; Kashima, S.; Marcussi, S.; Pereira, J.O.; Astolfi-Filho, S.; Nomizo, A.; Giglio, J.R.; Fontes, M.R.M.; Soares, A.M.; França, S.C. Cloning and identification of a complete CDNA coding for a bactericidal and antitumoral acidic phospholipase a2 from Bothrops Jararacussu Venom. Protein J. 2004, 23, 273-285. [CrossRef]

162. Santos-Filho, N.A.; Silveira, L.B.; Oliveira, C.Z.; Bernardes, C.P.; Menaldo, D.L.; Fuly, A.L.; Arantes, E.C.; Sampaio, S.V.; Mamede, C.C.N.; Beletti, M.E.; et al. A new acidic myotoxic, Anti-platelet and prostaglandin I2 inductor phospholipase A2 isolated from Bothrops Moojeni snake venom. Toxicon 2008, 52, 908-917. [CrossRef] [PubMed]

163. Silveira, L.B.; Marchi-Salvador, D.P.; Santos-Filho, N.A.; Silva, F.P.; Marcussi, S.; Fuly, A.L.; Nomizo, A.; da Silva, S.L.; Stábeli, R.G.; Arantes, E.C.; et al. Isolation and expression of a hypotensive and anti-platelet acidic phospholipase A2 from Bothrops Moojeni snake venom. J. Pharm. Biomed. Anal. 2013, 73, 35-43. [CrossRef]

164. De Albuquerque Modesto, J.C.; Spencer, P.J.; Fritzen, M.; Valença, R.C.; Oliva, M.L.V.; da Silva, M.B.; Chudzinski-Tavassi, A.M.; Guarnieri, M.C. BE-I-PLA2, a novel acidic phospholipase A2 from Bothrops Erythromelas venom: Isolation, cloning and characterization as potent anti-platelet and inductor of prostaglandin I2 release by endothelial cells. Biochem. Pharmacol. 2006, 72, 377-384. [CrossRef] [PubMed]

165. Naumann, G.B.; Silva, L.F.; Silva, L.; Faria, G.; Richardson, M.; Evangelista, K.; Kohlhoff, M.; Gontijo, C.M.F.; Navdaev, A.; de Rezende, F.F.; et al. Cytotoxicity and inhibition of platelet aggregation caused by an L-amino acid oxidase from Bothrops Leucurus venom. Biochim. Biophys. Acta 2011, 1810, 683-694. [CrossRef] [PubMed]

166. Sousa, L.F.; Bernardoni, J.L.; Zdenek, C.N.; Dobson, J.; Coimbra, F.; Gillett, A.; Lopes-Ferreira, M.; Moura-da-Silva, A.M.; Fry, B.G. Differential coagulotoxicity of metalloprotease isoforms from Bothrops Neuwiedi snake venom and consequent variations in antivenom efficacy. Toxicol. Lett. 2020, 333, 211-221. [CrossRef] 
167. Bourke, L.A.; Zdenek, C.N.; Neri-Castro, E.; Bénard-Valle, M.; Alagón, A.; Gutiérrez, J.M.; Sanchez, E.F.; Aldridge, M.; Fry, B.G. Pan-American lancehead Pit-vipers: Coagulotoxic venom effects and antivenom neutralisation of Bothrops Asper and B. atrox geographical variants. Toxins 2021, 13, 78. [CrossRef] [PubMed]

168. Nielsen, V.G.; Frank, N.; Afshar, S. De novo assessment and review of pan-american pit viper anticoagulant and procoagulant venom activities via kinetomic analyses. Toxins 2019, 11, 94. [CrossRef]

169. Berger, M.; Pinto, A.F.M.; Guimarães, J.A. Purification and Functional characterization of bothrojaractivase, a prothrombinactivating metalloproteinase isolated from Bothrops Jararaca snake venom. Toxicon 2008, 51, 488-501. [CrossRef]

170. Kini, R.M.; Koh, C.Y. Metalloproteases affecting blood coagulation, fibrinolysis and platelet aggregation from snake venoms: Definition and nomenclature of interaction sites. Toxins 2016, 8, 284. [CrossRef] [PubMed]

171. Kini, R.M. The intriguing world of prothrombin activators from snake venom. Toxicon 2005, 45, 1133-1145. [CrossRef] [PubMed]

172. Hofmann, H.; Bon, C. Blood coagulation induced by the venom of Bothrops Atrox. 2. identification, purification, and properties of two factor X activators. Biochemistry 1987, 26, 780-787. [CrossRef]

173. Niewiarowski, S.; Kirby, E.P.; Brudzynski, T.M.; Stocker, K. Thrombocytin, a serine protease from Bothrops Atrox venom. 2. interaction with platelets and plasma-clotting factors. Biochemistry 1979, 18, 3570-3577. [CrossRef] [PubMed]

174. Rosing, J.; Govers-Riemslag, J.W.; Yukelson, L.; Tans, G. Factor V activation and inactivation by venom proteases. Haemostasis 2001, 31, 241-246. [CrossRef] [PubMed]

175. Duarte, R.C.F.; Rios, D.R.A.; Leite, P.M.; Alves, L.C.; Magalhães, H.P.B.; das Graças Carvalho, M. Thrombin generation test for evaluating hemostatic effects of Brazilian snake venoms. Toxicon 2019, 163, 36-43. [CrossRef]

176. Isbister, G.K. Snakebite doesn't cause disseminated intravascular coagulation: Coagulopathy and thrombotic microangiopathy in snake envenoming. Semin. Thromb. Hemost. 2010, 36, 444-451. [CrossRef]

177. Castro, H.C.; Zingali, R.B.; Albuquerque, M.G.; Pujol-Luz, M.; Rodrigues, C.R. Snake venom thrombin-like enzymes: From reptilase to now. Cell. Mol. Life Sci. 2004, 61, 843-856. [CrossRef]

178. Sachetto, A.T.A.; Mackman, N. Modulation of the mammalian coagulation system by venoms and other proteins from snakes, arthropods, nematodes and insects. Thromb. Res. 2019, 178, 145-154. [CrossRef]

179. Pérez, A.V.; Saravia, P.; Rucavado, A.; Sant'Ana, C.D.; Soares, A.M.; Gutiérrez, J.M. Local and systemic pathophysiological alterations induced by a serine proteinase from the venom of the snake Bothrops Jararacussu. Toxicon 2007, 49, 1063-1069. [CrossRef] [PubMed]

180. Yamashita, K.M.; Alves, A.F.; Barbaro, K.C.; Santoro, M.L. Bothrops Jararaca venom metalloproteinases are essential for coagulopathy and increase plasma tissue factor levels during envenomation. PLoS Negl. Trop. Dis. 2014, 8, e2814. [CrossRef]

181. Zingali, R.B.; Jandrot-Perrus, M.; Guillin, M.C.; Bon, C. Bothrojaracin, a new thrombin inhibitor isolated from Bothrops Jararaca venom: Characterization and mechanism of thrombin inhibition. Biochemistry 1993, 32, 10794-10802. [CrossRef]

182. Arocas, V.; Zingali, R.B.; Guillin, M.C.; Bon, C.; Jandrot-Perrus, M. Bothrojaracin: A potent two-site-directed thrombin inhibitor. Biochemistry 1996, 35, 9083-9089. [CrossRef]

183. Sekiya, F.; Atoda, H.; Morita, T. Isolation and characterization of an anticoagulant protein homologous to botrocetin from the venom of Bothrops Jararaca. Biochemistry 1993, 32, 6892-6897. [CrossRef]

184. Patiño, A.C.; Pereañez, J.A.; Núñez, V.; Benjumea, D.M.; Fernandez, M.; Rucavado, A.; Sanz, L.; Calvete, J.J. Isolation and biological characterization of Batx-I, a weak hemorrhagic and fibrinogenolytic pi metalloproteinase from Colombian Bothrops Atrox venom. Toxicon 2010, 56, 936-943. [CrossRef]

185. Kamiguti, A.S.; Slupsky, J.R.; Zuzel, M.; Hay, C.R. Properties of fibrinogen cleaved by Jararhagin, a metalloproteinase from the venom of Bothrops Jararaca. Thromb. Haemost. 1994, 72, 244-249. [CrossRef] [PubMed]

186. Sugiki, M.; Maruyama, M.; Yoshida, E.; Mihara, H.; Kamiguti, A.S.; Theakston, D.G. Enhancement of plasma fibrinolysis in vitro by Jararhagin, the main haemorrhagic metalloproteinase in Bothrops Jararaca venom. Toxicon 1995, 33, 1605-1617. [CrossRef]

187. Carone, S.E.I.; Menaldo, D.L.; Sartim, M.A.; Bernardes, C.P.; Caetano, R.C.; da Silva, R.R.; Cabral, H.; Barraviera, B.; Ferreira Junior, R.S.; Sampaio, S.V. BjSP, a novel serine protease from Bothrops Jararaca snake venom that degrades fibrinogen without forming fibrin clots. Toxicol. Appl. Pharmacol. 2018, 357, 50-61. [CrossRef] [PubMed]

188. Sant' Ana, C.D.; Ticli, F.K.; Oliveira, L.L.; Giglio, J.R.; Rechia, C.G.V.; Fuly, A.L.; Selistre de Araújo, H.S.; Franco, J.J.; Stabeli, R.G.; Soares, A.M.; et al. BjussuSP-I: A new thrombin-like enzyme isolated from Bothrops Jararacussu snake venom. Comp. Biochem. Physiol. Part A Mol. Integr. Physiol. 2008, 151, 443-454. [CrossRef]

189. Urano, T.; Ihara, H.; Takada, Y.; Fujie, M.; Takada, A. The cleavage and Inactivation of plasminogen activator inhibitor type 1 and Alpha2-antiplasmin by reptilase, a thrombin-like venom enzyme. Blood Coagul. Fibrinolysis 2000, 11, 145-153. [CrossRef]

190. Queiroz, L.S.; Santo Neto, H.; Rodrigues-Simioni, L.; Prado-Franceschi, J. Muscle necrosis and regeneration after envenomation by Bothrops Jararacussu snake venom. Toxicon 1984, 22, 339-346. [CrossRef]

191. Cogo, J.C.; Prado-Franceschi, J.; Cruz-Hofling, M.A.; Corrado, A.P.; Rodrigues-Simioni, L. Effect of bothrops insularis venom on the mouse and chick nerve-muscle preparation. Toxicon 1993, 31, 1237-1247. [CrossRef]

192. Assafim, M.; Ferreira, M.S.; Frattani, F.S.; Guimarães, J.A.; Monteiro, R.Q.; Zingali, R.B. Counteracting effect of glycyrrhizin on the hemostatic abnormalities induced by Bothrops Jararaca Snake venom. Br. J. Pharmacol. 2006, 148, 807-813. [CrossRef]

193. Fernandes, R.S.; Assafim, M.; Arruda, E.Z.; Melo, P.A.; Zingali, R.B.; Monteiro, R.Q. Suramin counteracts the haemostatic disturbances produced by Bothrops Jararaca snake venom. Toxicon 2007, 49, 931-938. [CrossRef] 
194. Burdmann, E.A.; Woronik, V.; Prado, E.B.; Abdulkader, R.C.; Saldanha, L.B.; Barreto, O.C.; Marcondes, M. Snakebite-induced acute renal failure: An experimental model. Am. J. Trop. Med. Hyg. 1993, 48, 82-88. [CrossRef]

195. Silva, M.B.; Schattner, M.; Ramos, C.R.R.; Junqueira-de-Azevedo, I.L.M.; Guarnieri, M.C.; Lazzari, M.A.; Sampaio, C.A.M.; Pozner, R.G.; Ventura, J.S.; Ho, P.L.; et al. A prothrombin activator from Bothrops Erythromelas (Jararaca-Da-Seca) snake venom: Characterization and molecular cloning. Biochem. J. 2003, 369, 129-139. [CrossRef]

196. Pereira, A.L.; Fritzen, M.; Faria, F.; Motta, G.; Chudzinski-Tavassi, A.M. Releasing or expression modulating mediator involved in hemostasis by Berythractivase and Jararhagin (SVMPs). Toxicon 2006, 47, 788-796. [CrossRef]

197. Mota, S.M.B.; Albuquerque, P.L.M.M.; Meneses, G.C.; da Silva Junior, G.B.; Martins, A.M.C.; De Francesco Daher, E. Role of endothelial biomarkers in predicting acute kidney injury in Bothrops Envenoming. Toxicol. Lett. 2021, 345, 61-66. [CrossRef]

198. Sartim, M.A.; Cezarette, G.N.; Jacob-Ferreira, A.L.; Frantz, F.G.; Faccioli, L.H.; Sampaio, S.V. Disseminated Intravascular Coagulation Caused by Moojenactivase, a Procoagulant Snake Venom Metalloprotease. Int. J. Biol. Macromol. 2017, 103, 1077-1086. [CrossRef]

199. Sanders, W.E.; Read, M.S.; Reddick, R.L.; Garris, J.B.; Brinkhous, K.M. Thrombotic thrombocytopenia with von willebrand factor deficiency induced by botrocetin. An animal model. Lab. Investig. 1988, 59, 443-452.

200. Vu, T.T.; Stafford, A.R.; Leslie, B.A.; Kim, P.Y.; Fredenburgh, J.C.; Weitz, J.I. Batroxobin binds fibrin with higher affinity and promotes clot expansion to a greater extent than thrombin. J. Biol. Chem. 2013, 288, 16862-16871. [CrossRef]

201. Wu, C.; Dong, N.; da Cunha, V.; Martin-McNulty, B.; Tran, K.; Nagashima, M.; Wu, Q.; Morser, J.; Wang, Y.-X. Activated thrombin-activatable fibrinolysis inhibitor attenuates spontaneous fibrinolysis of batroxobin-induced fibrin deposition in rat lungs. Thromb. Haemost. 2003, 90, 414-421. [CrossRef]

202. Herrera, C.; Rucavado, A.; Warrell, D.A.; Gutiérrez, J.M. Systemic effects induced by the venom of the Snake Bothrops Caribbaeus in a murine model. Toxicon 2013, 63, 19-31. [CrossRef]

203. Lôbo de Araújo, A.; Kamiguti, A.; Bon, C. Coagulant and anticoagulant activities of Bothrops Lanceolatus (Fer de Lance) venom. Toxicon 2001, 39, 371-375. [CrossRef]

204. McFarlane, P.A.; Bitzan, M.; Broome, C.; Baran, D.; Garland, J.; Girard, L.-P.; Grewal, K.; Lapeyraque, A.-L.; Patriquin, C.J.; Pavenski, K.; et al. Making the correct diagnosis in thrombotic microangiopathy: A narrative review. Can. J. Kidney Health Dis. 2021, 8, 20543581211008708. [CrossRef]

205. Joly, B.S.; Coppo, P.; Veyradier, A. An update on pathogenesis and diagnosis of thrombotic thrombocytopenic purpura. Expert Rev. Hematol. 2019, 12, 383-395. [CrossRef] [PubMed]

206. Joseph, A.; Cointe, A.; Mariani Kurkdjian, P.; Rafat, C.; Hertig, A. Shiga toxin-associated hemolytic uremic syndrome: A narrative review. Toxins 2020, 12, 67. [CrossRef] [PubMed]

207. Stroka, A.; Donato, J.L.; Bon, C.; Hyslop, S.; de Araújo, A.L. Purification and characterization of a hemorrhagic metalloproteinase from Bothrops Lanceolatus (Fer-de-Lance) snake venom. Toxicon 2005, 45, 411-420. [CrossRef] [PubMed]

208. Delafontaine, M.; Villas-Boas, I.M.; Mathieu, L.; Josset, P.; Blomet, J.; Tambourgi, D.V. Enzymatic and pro-inflammatory activities of Bothrops Lanceolatus venom: Relevance for envenomation. Toxins 2017, 9, 244. [CrossRef] [PubMed]

209. Ikeda, K.; Nagasawa, K.; Horiuchi, T.; Tsuru, T.; Nishizaka, H.; Niho, Y. C5a induces tissue factor activity on endothelial cells. Thromb. Haemost. 1997, 77, 394-398. [CrossRef] [PubMed]

210. Tedesco, F.; Pausa, M.; Nardon, E.; Introna, M.; Mantovani, A.; Dobrina, A. The cytolytically inactive terminal complement complex activates endothelial cells to express adhesion molecules and tissue factor procoagulant activity. J. Exp. Med. 1997, 185, 1619-1627. [CrossRef]

211. Delafontaine, M.; Villas-Boas, I.M.; Pidde, G.; van den Berg, C.W.; Mathieu, L.; Blomet, J.; Tambourgi, D.V. Venom from Bothrops Lanceolatus, a snake species native to martinique, potently activates the complement system. J. Immunol. Res. 2018, 2018, 3462136. [CrossRef]

212. Silva de França, F.; Gabrili, J.J.M.; Mathieu, L.; Burgher, F.; Blomet, J.; Tambourgi, D.V. Bothrops Lanceolatus snake (Fer-de-Lance) venom triggers inflammatory mediators' storm in human blood. Arch. Toxicol. 2021, 95, 1129-1138. [CrossRef]

213. Pidde-Queiroz, G.; Furtado Mde, F.; Filgueiras, C.F.; Pessoa, L.A.; Spadafora-Ferreira, M.; van den Berg, C.W.; Tambourgi, D.V. Human complement activation and anaphylatoxins generation induced by Snake venom toxins from Bothrops Genus. Mol. Immunol. 2010, 47, 2537-2544. [CrossRef] 